\title{
Benthic nutrient recycling on the northeastern shelf of the Gulf of Cádiz (SW Iberian Peninsula)
}

\author{
S. Ferrón ${ }^{1,4, *}$, F. Alonso-Pérez ${ }^{2}$, E. Anfuso ${ }^{1}$, F. J. Murillo ${ }^{3}$, T. Ortega ${ }^{1}$, \\ C. G. Castro ${ }^{2}$, J. M. Forja ${ }^{1}$ \\ ${ }^{1}$ Departamento de Química Física, Facultad de Ciencias del Mar y Ambientales, Universidad de Cádiz, \\ Campus Río San Pedro, s/n,11510 Puerto Real, Cádiz, Spain \\ ${ }^{2}$ Departamento de Oceanografía, Instituto de Investigaciones Marinas, CSIC, c/ Eduardo Cabello 6, 36208 Vigo, \\ Pontevedra, Spain \\ ${ }^{3}$ Departamento de Zooloxía e Antropoloxía Física, Facultade de Bioloxía, Universidade de Santiago de Compostela, \\ Campus Sur, 15782 Santiago de Compostela, A Coruña, Spain \\ ${ }^{4}$ Present address: Department of Oceanography, University of Hawaii, 1000 Pope Road, Honolulu, Hawaii 96822, USA
}

\begin{abstract}
Benthic fluxes of nutrients and dissolved nitrous oxide $\left(\mathrm{N}_{2} \mathrm{O}\right)$ were determined by benthic chamber incubations in 2 regions on the northeastern near-shore continental shelf of the Gulf of Cádiz (depth range: 8 to $34 \mathrm{~m}$ ), one off the Guadalquivir River mouth and the other in the Bay of Cádiz and its neighboring shelf. In total, 25 in situ benthic chamber incubations were performed during June 2006, November 2006, and February 2007 to investigate the main factors controlling benthic nutrient recycling and its significance at the study site. Nutrient benthic fluxes (in $\mathrm{m}^{-2} \mathrm{~d}^{-1}$ ) varied

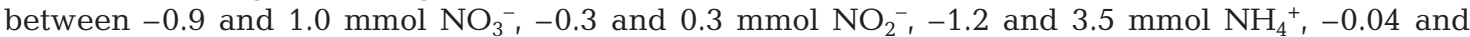

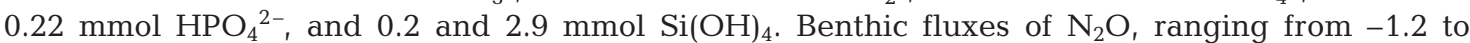
$10.4 \mu \mathrm{mol} \mathrm{N}-\mathrm{N}_{2} \mathrm{O} \mathrm{m}^{-2} \mathrm{~d}^{-1}$, accounted on average for $<1 \%$ of total inorganic nitrogen fluxes. The regeneration of $\mathrm{NH}_{4}{ }^{+}$and $\mathrm{Si}(\mathrm{OH})_{4}$ was mainly influenced by organic carbon oxidation rates and bulk organic carbon in surface sediments, whereas $\mathrm{HPO}_{4}{ }^{2-}$ regeneration was mostly influenced by bottom water oxygen concentration and water depth. Denitrification was estimated to account for between 9 and $13 \%$ of organic matter remineralization and for a loss of between 57 and $67 \%$ of potentially recyclable nitrogen. Overall, benthic remineralization was estimated to degrade about $47 \%$ of overlying primary production, supplying about 15 and $12 \%$ of the phytoplankton $\mathrm{N}$ and $\mathrm{P}$ requirements, respectively. This highlights the importance of benthic organic matter remineralization on the biogeochemistry of the northeastern continental shelf of the Gulf of Cádiz.
\end{abstract}

KEY WORDS: Benthic fluxes $\cdot$ Nutrient regeneration $\cdot$ Denitrification $\cdot$ Nitrous oxide $\cdot$ Macrofauna Coastal sediments · Gulf of Cádiz

\section{INTRODUCTION}

Continental shelf sediments are important sites for organic matter remineralization and nutrient recycling to the water column and therefore play a key role in controlling the biogeochemistry of these systems (e.g. Berelson et al. 1998, 2003, Hopkinson et al. 2001). Despite their modest surface area, continental shelves are biogeochemically very active sites, receive large amounts of dissolved and particulate terrestrial matter, and serve as a connection between the continents and the open ocean. About $25 \%$ of total oceanic primary production occurs on the continental shelves (Wollast 2002). Due to their shallowness, a large proportion of the autochthonous and allochthonous organic matter reaches the sediments, where it suffers a vertical sequence of fermentative and respiratory microbial processes that progressively use the oxidants that yield the greatest free energy $\left(\mathrm{O}_{2}, \mathrm{Mn}^{4+}, \mathrm{NO}_{3}{ }^{-}, \mathrm{Fe}^{3+}, \mathrm{SO}_{4}^{-}, \mathrm{HCO}_{3}^{-}\right)$. The presence of benthic fauna deeply affects the spatial dis- 
tribution of microbial biogeochemical zones, altering the physical and chemical properties of marine sediments and enhancing benthic remineralization processes (Aller \& Aller 1998, Mortimer et al. 1999, Wenzhöfer \& Glud 2004). Organic matter degradation in coastal sediments and the associated release of nutrients often provide a considerable fraction of phosphorus and nitrogen requirements for phytoplankton and can stimulate pelagic primary production (Nixon 1981, Cowan \& Boynton 1996, Herbert 1999, Gibbs et al. 2005).

Nitrogen cycling is especially critical in marine sediments due to denitrification, the anaerobic microbial reduction of nitrate $\left(\mathrm{NO}_{3}^{-}\right)$to nitrous oxide $\left(\mathrm{N}_{2} \mathrm{O}\right)$ and dinitrogen gas $\left(\mathrm{N}_{2}\right)$. More than $50 \%$ of nitrogen inputs to the ocean may be removed by benthic denitrification in continental margins (Christensen 1994). Nitrate for denitrification can either be supplied directly from the overlying water column or through sedimentary aerobic nitrification of ammonium (coupled nitrification/ denitrification; Seitzinger 1988). $\mathrm{N}_{2} \mathrm{O}$, a potent atmospheric greenhouse gas (Rodhe 1990) that is also involved in the depletion of stratospheric ozone (Crutzen \& Schmailzl 1983), is mainly produced in aquatic environments as an obligate intermediate during denitrification and as a byproduct in the first step of nitrification. Several authors have pointed out the importance of sediments as a major source of $\mathrm{N}_{2} \mathrm{O}$ in coastal systems (Robinson et al. 1998, Seitzinger et al. 2000, Bange 2006). About $13 \%$ of global $\mathrm{N}_{2} \mathrm{O}$ emission to the atmosphere occurs in the oceans (Khalil \& Rasmussen 1992), of which $35 \%$ to $60 \%$ is attributed to estuaries and near-shore coastal environments.

This work reports the results derived from in situ benthic chamber incubations performed in near-shore sediments of the northeastern shelf of the Gulf of Cádiz (SW Iberian Peninsula), during 3 periods of the year, corresponding to summer, autumn, and winter. Documented nutrient benthic flux measurements in this region have only been performed in shallower littoral sediments such as the inner Bay of Cádiz (GómezParra \& Forja 1992, Forja et al. 1994, Ferrón et al. 2009), where nutrient benthic fluxes were in the range of 3 to $24 \mathrm{mmol}$ $\mathrm{NH}_{4}{ }^{+} \mathrm{m}^{-2} \mathrm{~d}^{-1}, 0.2$ to $7.8 \mathrm{mmol} \mathrm{HPO}_{4}{ }^{2-} \mathrm{m}^{-2}$ $\mathrm{d}^{-1}$, and 1 to $28 \mathrm{mmol} \mathrm{Si}(\mathrm{OH})_{4} \mathrm{~m}^{-2} \mathrm{~d}^{-1}$. The main goals of this research were to analyze the principal factors controlling benthic organic matter decomposition and nutrient recycling in continental shelf sediments of the Gulf of Cádiz and to examine the significance of benthic nutrient regeneration in this system.

\section{MATERIALS AND METHODS}

Study site. The study was performed in the nearshore northeastern shelf of the Gulf of Cádiz (SW Iberian Peninsula), which is a wide basin between the Iberian Peninsula and the African continent where the North Atlantic Ocean and the Mediterranean Sea meet through the Strait of Gibraltar (Fig. 1). In particular, the northeastern shelf of the gulf receives freshwater inputs from several rivers (such as Guadiana, Guadalquivir, Tinto, and Odiel), and its circulation is mainly controlled by the North Atlantic Surface Water (NASW), which flows towards the east and southeast to the Strait of Gibraltar, as well as by an intermittent counter current system that seems to be closely linked to the wind regime (Lobo et al. 2004). Phytoplankton distribution is tightly coupled to meteorological and hydrodynamic conditions in this sector of the gulf, which presents the highest primary production within the basin (Navarro \& Ruiz 2006). Predominance of westerly winds favors the generation of upwelling events and therefore an increase in primary production, whereas easterlies lead to a decrease in phytoplankton (Navarro \& Ruiz 2006).

Nine sites were selected in near-shore waters close to the mouth of the Guadalquivir River (GL1 to GL4) and the Bay of Cádiz (BC1 to BC5; Fig. 1). The Guadalquivir River is the main fluvial source draining into the Gulf of Cádiz, with an annual water discharge of $160 \mathrm{~m}^{3} \mathrm{~s}^{-1}$ (Van Geen et al. 1997). The river is $560 \mathrm{~km}$

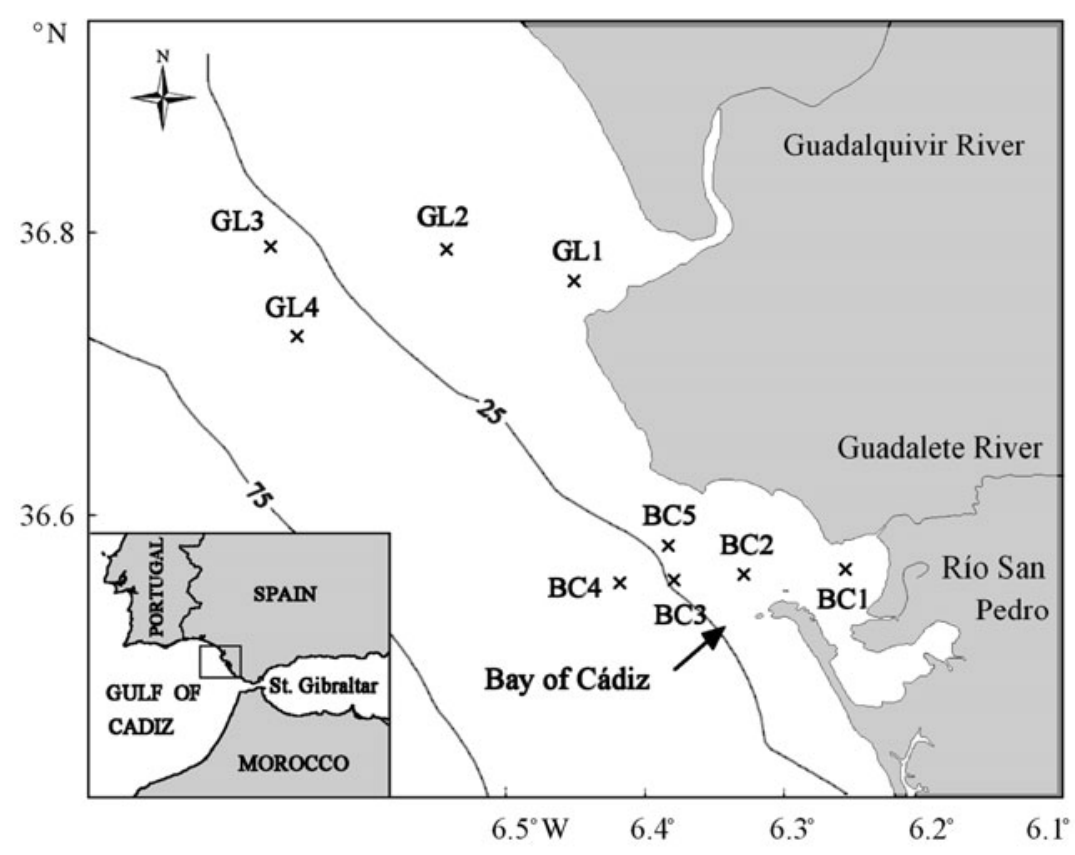

Fig. 1. Near-shore northeastern shelf of the Gulf of Cádiz showing the sampling sites and the location of the rivers and the Bay of Cádiz. Isolines represent the bathymetry in meters 
long, and its drainage basin covers an area of approximately $58000 \mathrm{~km}^{2}$. The estuary is characterized by an irregular river discharge, which is relatively low for most of the year and considerably higher during the rainy season (February to March; de la Paz et al. 2007). The hydrodynamics in the estuary are mainly controlled by the tidal regime. On the other hand, the Bay of Cádiz is a shallow environment divided into 2 basins: the southern and shallower inner bay, and the northern and deeper outer bay $\left(88 \mathrm{~km}^{2}\right)$, which is connected to the gulf through a $13.5 \mathrm{~km}$ wide mouth. The bay is surrounded by an extensive salt marsh area and several towns and cities, with a total population of about 700000 inhabitants. The $157 \mathrm{~km}$ long Guadalete River, which receives the effluent of the wastewater treatment plant of Jerez de la Frontera (200 000 inhabitants) and the drainage from agricultural cultivations, flows into the outer bay. Nearby, a shallow tidal creek (Río San Pedro), affected by the discharges from surrounding aquaculture installations (Tovar et al. 2000), also flows into the bay.

The data reported in this work were collected during 3 cruises on board RV 'Mytilus,' covering 3 seasonal periods: June 2006, November 2006, and February 2007. At each site, CTD casts were performed at the beginning of the chamber incubations to obtain the vertical profiles of temperature, salinity, pressure, dissolved oxygen, and fluorescence, by means of a Seabird CTD probe coupled to a Seatech fluorometer and a Seabird 43 (SBE-43) dissolved oxygen sensor. Surface and bottom waters were sampled for analysis of nutrients, and nitrous oxide. The surface sediment was sampled at the beginning of each incubation by means of a box-corer $(15 \times 10 \mathrm{~cm})$ to measure total $\mathrm{C}$ and $\mathrm{N}$ composition and organic carbon content in the top centimeter, and with a Van Veen drag to measure grain size distribution.

In situ benthic flux measurements. The fluxes of nutrients and nitrous oxide were measured by in situ benthic chamber incubations, using an opaque cylindrical stirred chamber $(0.8 \mathrm{~m}$ inner diameter, $0.28 \mathrm{~m}$ height) that covers $0.50 \mathrm{~m}^{2}$ of sea bottom and approximately 1401 of overlying water (Ferrón et al. 2008). Stirring of the water phase is achieved by means of 3 centrifugal pumps. Inside the chamber, sensors for temperature (SBE-39), pH (SBE-18), oxygen (SBE-43), and turbidity (Seapoint Turbidity Meter) give a continuous recording of these variables during the incubations. Real time monitoring and data acquisition are achieved by means of a 2 -way radio communication system (SATELLINE-3AS, SATEL). A multiple water sampler provided with 12 syringes (KC-Denmark) collects discrete $50 \mathrm{ml}$ samples at pre-set time intervals. The chamber was slowly lowered to the bottom from the ship with a crane. The incubations were performed during the day and lasted for approximately $8 \mathrm{~h}$. Nutrient samples were filtered (Polycarbonate, $0.45 \mu \mathrm{m}$ ) and kept frozen until subsequent analysis. Samples for $\mathrm{N}_{2} \mathrm{O}$ measurements were carefully drawn into $25 \mathrm{ml}$ airtight glass bottles, preserved with saturated mercuric chloride, sealed with Apiezon ${ }^{\circledR}$ grease and stored in the dark until analysis in the laboratory.

Analytical methods. Nitrate, nitrite, ammonium, phosphate, and silicate were determined by segmented flow analysis with Alpkem autoanalyzers following Hansen \& Grassoff (1983), with some improvements (Mouriño \& Fraga 1985). The storage of silicate samples by freezing is satisfactory for samples with a silicate content below $50 \mathrm{\mu mol} \mathrm{l}^{-1}$ (Koroleff 1983). Silicon tends to polymerize when stored frozen and hence samples must be allowed to stand for at least $3 \mathrm{~h}$ after thawing, and were shaken vigorously before analysis. The analytical errors were $\pm 0.05 \mu \mathrm{mol} \mathrm{kg}{ }^{-1}$ for nitrate, ammonium, and silicate, $\pm 0.02 \mu \mathrm{mol} \mathrm{kg}{ }^{-1}$ for nitrite, and $\pm 0.01 \mu \mathrm{mol} \mathrm{kg}{ }^{-1}$ for phosphate.

Dissolved $\mathrm{N}_{2} \mathrm{O}$ concentrations were determined with a gas chromatograph (Varian CX 3600). In-syringe head space equilibration was used to extract the dissolved gas from the water samples. The temperature of equilibration $\left( \pm 0.1^{\circ} \mathrm{C}\right)$ was registered by a thermometer (P500 Dostman electronic). A mixture of $\mathrm{Ar} / \mathrm{CH}_{4}$ $(95 \% / 5 \%)$ was used as carrier gas $\left(30 \mathrm{ml} \mathrm{min}^{-1}\right)$, gases were separated by a $2.5 \mathrm{~m} \times 1 / 8$ inch (ca. $0.32 \mathrm{~cm}$ ) stainless steel Porapack $\mathrm{N}$ column (80/10), and $\mathrm{N}_{2} \mathrm{O}$ was detected by a ${ }^{63} \mathrm{Ni}$ Electron Capture Detector (ECD), operated at $300^{\circ} \mathrm{C}$. The detector was calibrated using 3 standard gas mixtures distributed and certified by Air Liquide, with certified $\mathrm{N}_{2} \mathrm{O}$ concentrations of $0.264,0.840$, and 1.55 ppmv. The precision of the method, including the equilibration step, was $6.6 \%$, expressed as the variation coefficient based on replicate analysis $(\mathrm{n}=25)$ of a seawater sample saturated with $\mathrm{N}_{2} \mathrm{O}$. The concentration of $\mathrm{N}_{2} \mathrm{O}$ in the water samples was calculated from the concentration measured in the head space, using Bunsen solubility equations given by Weiss \& Price (1980).

Total $\mathrm{C}$ and $\mathrm{N}$ were measured in dried sediment (first $\mathrm{cm}$ ) on a CHNS-932-LECO Element Analyzer after $\mathrm{Cr}_{2} \mathrm{O}_{3}$ and $\mathrm{AgCo}_{3} \mathrm{O}_{4}$ had catalyzed oxidation and segregation on a Haysep-Q-column. The organic C content in surface sediments was determined by chemical oxidation (Gaudette et al. 1974, El Rayis 1985) with a standard deviation of $\pm 0.25 \%$.

Grain size distribution in surface sediments was measured by sieving, except for the fraction smaller than $63 \mu \mathrm{m}$, which was determined with a laser diffraction analyzer. Analysis of grain size statistics was carried out using the software GRADISTAT (Blott \& Pye 2001).

Macrofauna. During the survey in November 2006, macrofaunal samples were collected at each station 
with a Van Veen grab (sampling area: $0.1 \mathrm{~m}^{2}$ ), and sieved over a $1 \mathrm{~mm}$ mesh-sized sieve. Recovered material was preserved in $4 \%$ buffered formaldehyde. The preserved samples were sorted and identified. The abundance of each taxonomic group was recorded, and the wet weight of each species from each station was calculated. Wet weights were transformed to ash-free dry weights (AFDW) using published conversion factors for major taxa (Ricciardi \& Bourget 1998). Trophic guilds of the sampled macrofaunal species were determined from Parada (2005), based on Pearson (1971), Fauchald \& Jumars (1979), and other different works.

Benthic flux and rate calculations. Fluxes across the sediment-water interface were calculated as the product of the chamber height and the slope of the linear regression of the time series concentration evolution. Errors in benthic fluxes were derived from the error of the slope resulting from the data fit.

Denitrification rates: Total denitrification rates $\left(F_{\text {denit }}\right)$ were estimated, assuming that nitrate reduction is the dominant $\mathrm{N}_{2}$-producing process in the sediments, following the equation:

$$
F_{\text {denit }}=(1 / \mathrm{C}: \mathrm{N}) \times \mathrm{C}_{\mathrm{ox}}-F_{\mathrm{IN}}
$$

where $\mathrm{C}_{\mathrm{ox}}$ is the carbon mineralization rate, which were taken from a parallel study (Ferrón et al. unpubl.), and $F_{\mathrm{IN}}$ is the measured flux of dissolved inorganic nitrogen $\left(\mathrm{NO}_{3}{ }^{-}+\mathrm{NO}_{2}{ }^{-}+\mathrm{NH}_{4}{ }^{+}\right)$. Associated carbon mineralized via denitrification was estimated from the stoichiometry of the reaction (Froelich et al. 1979):

$\left(\mathrm{CH}_{2} \mathrm{O}\right)_{106}\left(\mathrm{NH}_{3}\right)_{16}\left(\mathrm{H}_{3} \mathrm{PO}_{4}\right)+84.8 \mathrm{HNO}_{3} \rightarrow$

$106 \mathrm{CO}_{2}+42.4 \mathrm{~N}_{2}+16 \mathrm{NH}_{3}+\mathrm{H}_{3} \mathrm{PO}_{4}+148.4 \mathrm{H}_{2} \mathrm{O}$

Nitrification rates: Nitrification rates $\left(F_{\text {nit }}\right)$ were calculated as the difference between total organic N mineralized and ammonium flux $\left(F_{\mathrm{NH} 4}\right)$ (Lehmann et al. 2004):

$$
F_{\text {nit }}=(1 / \mathrm{C}: \mathrm{N}) \times \mathrm{C}_{\mathrm{ox}}-F_{\mathrm{NH} 4}
$$

The first term of Eqs (1) \& (3) represents the total organic $\mathrm{N}$ mineralized and depends on the $\mathrm{C}: \mathrm{N}$ atomic ratio of organic matter undergoing diagenesis. In the study site, the organic matter deposited into the sediments is likely influenced by the supplies of terrestrial carbon discharged by the Guadalquivir and Guadalete rivers, as well as by autochthonous phytoplanktonderived material. Therefore, the $\mathrm{C}: \mathrm{N}$ ratio of degrading organic matter is expected to range from the Redfield ratio for phytoplankton $(\mathrm{C}: \mathrm{N}=6.6)$ to the $\mathrm{C}: \mathrm{N}$ ratio measured in the top centimeter of sediment. Consequently, to delimit the upper and lower limits of denitrification and nitrification rates, these were calculated assuming both Redfield and sediment $\mathrm{C}: \mathrm{N}$ ratios for organic matter.
$P$ recycling efficiency: $P$ recycling efficiency $\% \mathrm{P}_{\text {recyc }}$ was calculated as the percentage of measured phosphate fluxes $\left(F_{\mathrm{HPO} 4}\right)$ relative to the expected $F_{\mathrm{HPO} 4}$ from organic carbon remineralization assuming Redfield stoichiometry, by applying the expression:

$$
\% \mathrm{P}_{\text {recyc }}=100 \times\left[F_{\mathrm{HPO} 4} /\left(\mathrm{C}_{\mathrm{ox}} \times 1 / \mathrm{C}: \mathrm{P}\right)\right]
$$

In this case, calculations were only based on the Redfield stoichiometry ratio ( $\mathrm{C}: \mathrm{p}=106: 1$ ), as the sediment C:P ratio was not available. Therefore, these estimates are likely a lower limit for P recycling efficiency.

Statistical analysis. Seasonal and spatial (between GL and BC sites) differences of sediment properties and benthic fluxes were analyzed by using 1-way analysis of variance (ANOVA) followed by Bonferroni post hoc test (Statgraphics Plus 5.1). The threshold value for statistical difference was assumed to be $\mathrm{p}<0.05$. Relationships between sediment and bottom water properties and sediments were assessed using Principal Components Analysis (PCA) (Statgraphics Plus 5.1).

\section{RESULTS}

\section{Water column characteristics}

Water temperature varied seasonally, with highest temperatures in the summer and lowest in the winter (Fig. 2). Temperature differences between surface and bottom waters were mainly observed at GL sites during the summer. During autumn and winter, salinity values in surface waters were generally lower than in bottom waters, due to the influence of terrestrial freshwater inputs. Bottom water oxygen concentrations ranged from 163 to $248 \mu \mathrm{M}$, corresponding to atmospheric saturations of $62 \%$ and $99 \%$, respectively. Oxygen concentrations were significantly lower in the summer than in the winter $(\mathrm{p}<0.05)$. Water column nutrient concentrations (only nitrate shown) were significantly lower for the summer than the autumn and winter periods $(\mathrm{p}<0.01)$. Whereas $\mathrm{HPO}_{4}{ }^{2-}$ concentrations where in most cases above $0.05 \mu \mathrm{M}$, the concentration of nitrate was, during the summer and mostly in surface waters, often below $0.5 \mu \mathrm{M}$, which is considered limiting to phytoplankton growth (Fasham et al. 1990). Sea surface concentrations of nitrate, nitrite, phosphate, and silicate were directly influenced by freshwater supply, as indicated by a negative linear relationship with salinity $\left(\mathrm{r}^{2}=0.80\right.$ for $\mathrm{NO}_{3}{ }^{-}+\mathrm{NO}_{2}{ }^{-}, \mathrm{r}^{2}=$ 0.61 for $\mathrm{PO}_{4}{ }^{-}$, and $\mathrm{r}^{2}=0.71$ for $\left.\mathrm{Si}[\mathrm{OH}]_{4}\right)$. Nitrous oxide concentrations were significantly lower during the winter compared to autumn and summer ( $\mathrm{p}<0.01$ ). The water column was in all cases $\mathrm{N}_{2} \mathrm{O}$ oversaturated with respect to atmosphere, with saturations ranging from 220 to $340 \%, 230$ to $290 \%$, and 120 to $155 \%$ during summer, autumn, and winter, respectively. 

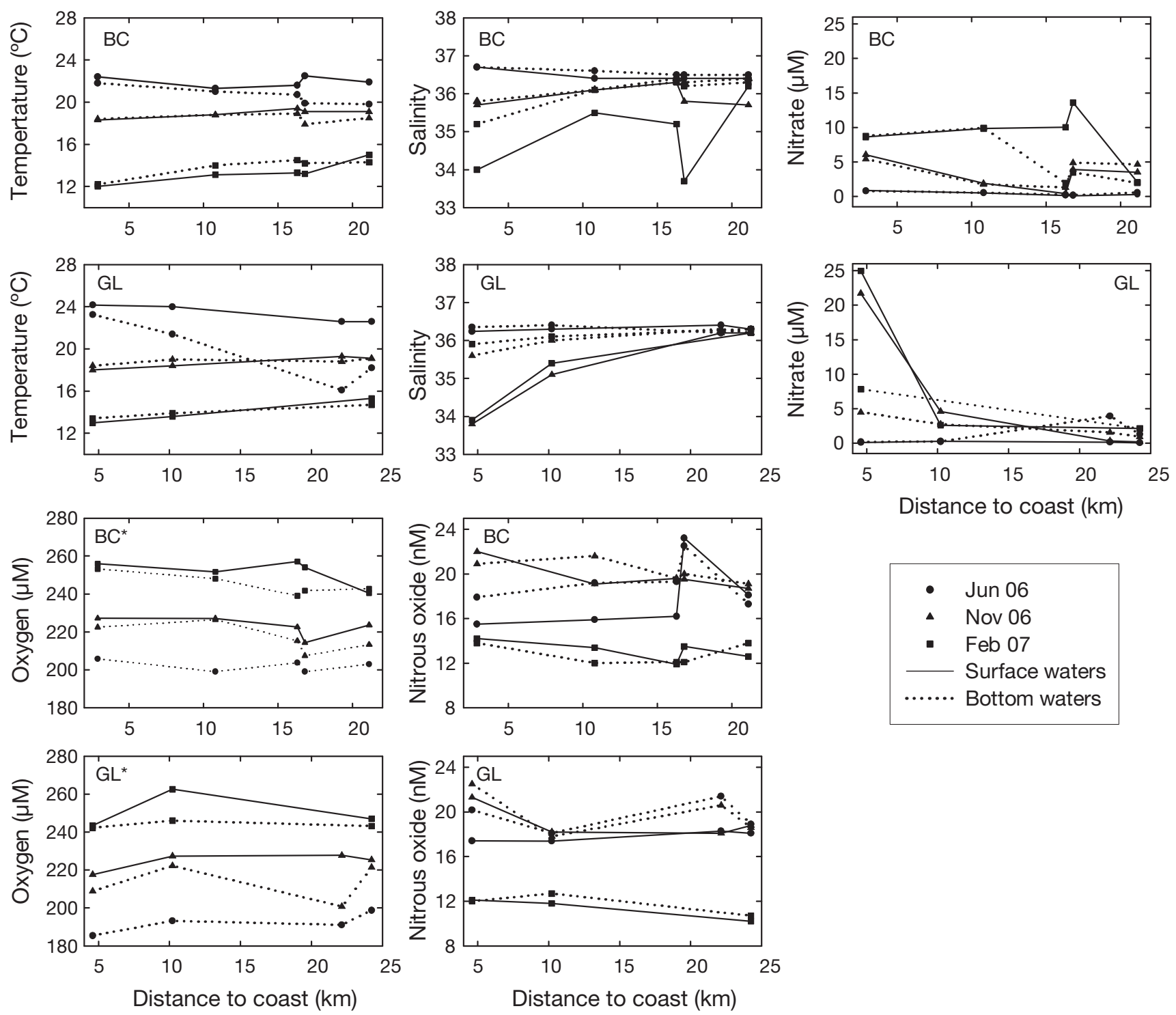

Fig. 2. Surface and bottom water characteristics at the beginning of each chamber incubation vs. distance to the coast for BC and GL sites. Due to technical problems, surface water oxygen concentrations for June 2006 were not available, and bottom water concentrations were taken from the oxygen sensor mounted in the benthic chamber

\section{Sediment characteristics}

Sediment from GL stations was characterized as mud (GL4, GL2, and GL3) and sandy mud (GL1), with a mud:sand ratio higher than 8:1 and negligible gravel content. The BC sites showed a higher fraction of sand. Sediments at BC1 and BC3 were characterized as muddy sands with a sand:mud ratio close to 9:1, whereas $\mathrm{BC} 2, \mathrm{BC} 4$, and $\mathrm{BC} 5$ were muddy sands with similar proportions of sand and mud but characterized by different fractions of gravel $(1 \%$ in BC2 and $5 \%$ in BC4 and BC5). Coarse material was mostly calcareous shell fragments. Average organic carbon for each site ranged from 0.25 to $1.18 \%$ and was significantly higher at GL sites than at BC sites ( $\mathrm{p}<0.01$; Table 1). Sediment nitrogen contents ranged from $0.03 \%$ to $0.18 \%$, and also showed significantly lower values $(\mathrm{p}<$ $0.01)$ at BC stations than at GL stations. The C:N molar ratios in surface sediments ranged from 7.0 to 9.4 and were not significantly different in GL and BC sites.

\section{Macrofauna}

In total, 97 benthic macrofaunal taxa were identified in the study area in November 2006 (see Appendix 1). Total macrofaunal abundances and biomass ranged from 660 to 2570 ind. $\mathrm{m}^{-2}$ and from 0.4 to $6.9 \mathrm{~g} \mathrm{~m}^{-2}$, 
Table 1. Depth, sediment organic carbon content $\left(\mathrm{OC}_{i}\right.$ mean \pm $\mathrm{SD})$, nitrogen content $\left(\mathrm{TN}_{\text {; }}\right.$ mean $\left.\pm \mathrm{SD}\right)$, molar $\mathrm{C}: \mathrm{N}$ ratio, and median grain size $\left(D_{50}\right)$ for each station

\begin{tabular}{|cccccc|}
\hline Stn & Depth $(\mathrm{m})$ & OC & TN & C:N & $D_{50}$ \\
\hline BC1 & 8 & $0.25 \pm 0.01$ & $0.04 \pm 0.01$ & 8.2 & 372 \\
BC2 & 18 & $0.47 \pm 0.15$ & $0.06 \pm 0.02$ & 8.8 & 61 \\
BC3 & 22 & $0.29 \pm 0.04$ & $0.03 \pm 0.01$ & 8.4 & 421 \\
BC4 & 32 & $0.64 \pm 0.03$ & $0.08 \pm 0.01$ & 8.8 & 78 \\
BC5 & 22 & $0.75 \pm 0.28$ & $0.12 \pm 0.07$ & 7.0 & 76 \\
GL1 & 13 & $1.18 \pm 0.25$ & $0.18 \pm 0.03$ & 7.9 & 12 \\
GL2 & 18 & $0.83 \pm 0.05$ & $0.11 \pm 0.01$ & 8.4 & 13 \\
GL3 & 29 & $0.80 \pm 0.07$ & $0.12 \pm 0.01$ & 9.4 & 27 \\
GL4 & 34 & $0.93 \pm 0.03$ & $0.14 \pm 0.01$ & 7.7 & 6.8 \\
\hline
\end{tabular}

respectively. Polychaeta was the dominant class and accounted for more than $45 \%$ of total biomass at all sites except BC2 and BC3 (Fig. 3a). The polychaete population was mainly dominated by small opportunistic polychaetes belonging to the families Lumbrineridae, Spionidae, Paraonidae, Capitellidae, Magelonidae, and Sternaspis scutata, or the large and active irrigating polychaete climax species such as Maldane glebifex or Glycera unicornis in BC4 and

a
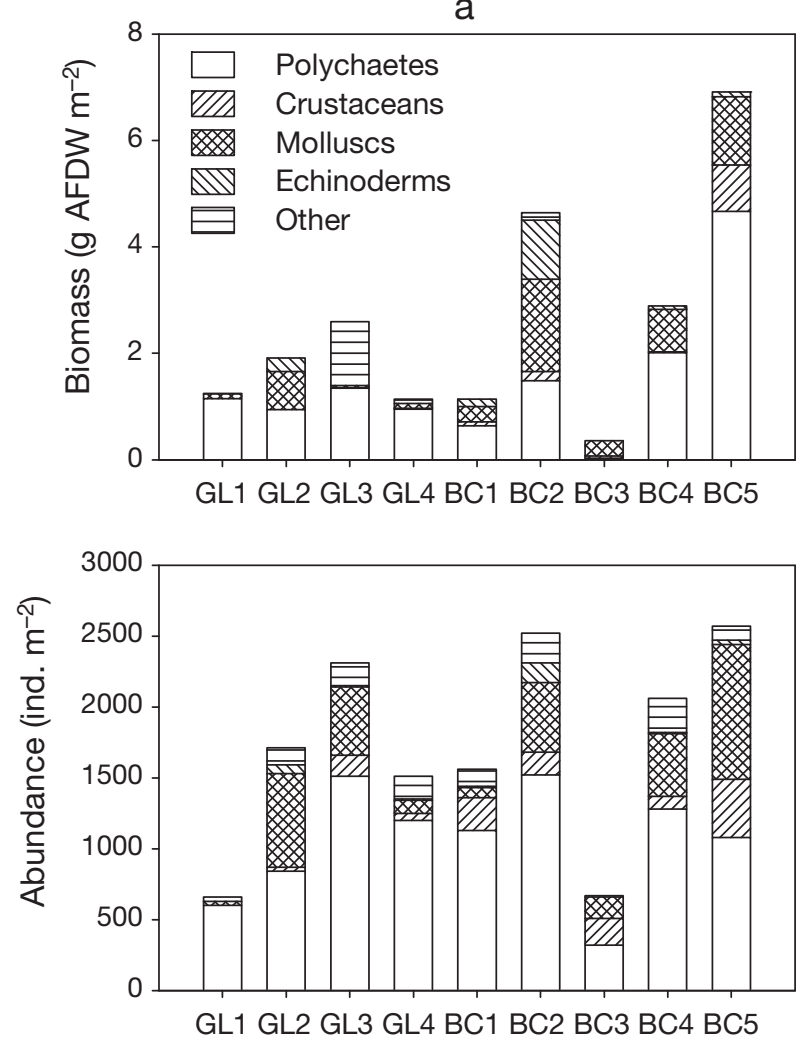

BC5. Molluscs were the next dominant macrofaunal class in most sites, with biomass ranging from 0.04 to $1.28 \mathrm{~g} \mathrm{~m}^{-2}$.

Surface deposit feeders were the dominant macrofaunal trophic group in terms of abundance, with the exceptions of GL1 and GL4 (Fig. 3b). At most of the stations, the dominance was well distributed among different groups except for sites GL3, BC5, BC2, and BC4. In terms of total biomass, carnivores accounted for more than $60 \%$ of total biomass in GL3 and BC5, mainly as a result of the presence of the nemertean Cerebratulus sp. and the burrowing polychaete Glycera unicornis, respectively. On the other hand, at sites $\mathrm{BC} 2$ and $\mathrm{BC} 4$, surface deposit feeders dominated due to the presence of the urchin Echinocardium cordatum at BC2 and tube-dwellers of the family Maldanidae at BC4.

\section{Benthic fluxes}

Nitrate fluxes ranged from -0.9 to $1.0 \mathrm{mmol} \mathrm{m}^{-2} \mathrm{~d}^{-1}$, whereas nitrite fluxes varied between -0.25 and 0.26 $\mathrm{mmol} \mathrm{m} \mathrm{m}^{-2} \mathrm{~d}^{-1}$ (Table 2). Twice in November 2006 and 3 times in February 2007, nitrate and nitrite fluxes were
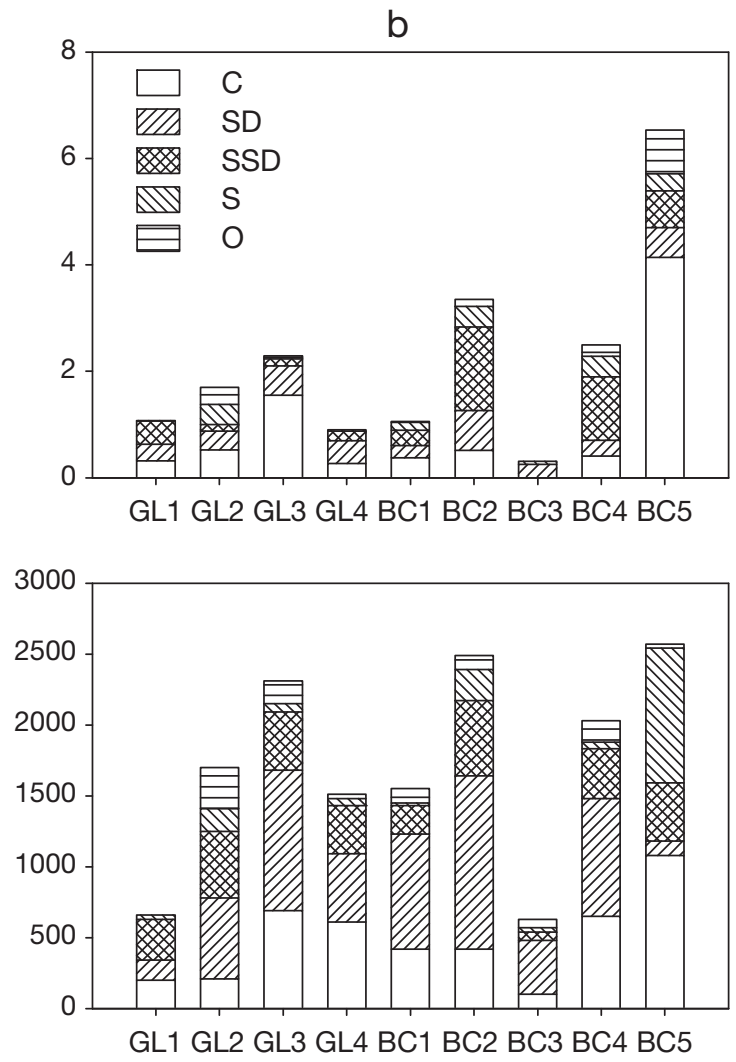

Fig. 3. Total biomass (g AFDW $\mathrm{m}^{-2}$ ) and total abundance (ind. $\mathrm{m}^{-2}$ ) (a) of the macrofaunal groups at each station; and (b) of the

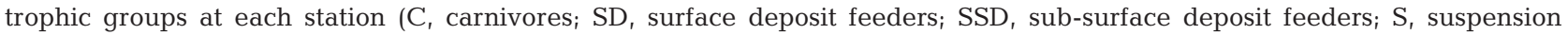
feeders; $\mathrm{O}$, others) 
Table 2. Date of sampling and benthic fluxes of nitrate $\left(F_{\mathrm{NO} 3}\right)$, nitrite $\left(F_{\mathrm{NO} 2}\right)$, ammonium $\left(F_{\mathrm{NH} 4}\right)$, phosphate $\left(F_{\mathrm{HPO} 4}\right)$, silicate $\left(F_{\mathrm{Si}}\right)$, and nitrous oxide $\left(F_{\mathrm{N} 2 \mathrm{O}}\right)$ for each station. Units in $\mathrm{mmol} \mathrm{m} \mathrm{m}^{-2} \mathrm{~d}^{-1}$, except for nitrous oxide $\left(\mu \mathrm{mol} \mathrm{m}^{-2} \mathrm{~d}^{-1}\right)$. Negative values denote fluxes into the sediment. Uncertainties are estimated from the errors in the slope of the regression of concentration with time, multiplied by the height of the benthic chamber. nm: not measurable

\begin{tabular}{|c|c|c|c|c|c|c|c|}
\hline Site & Date & $F_{\mathrm{NO} 3}$ & $F_{\mathrm{NO} 2}$ & $F_{\mathrm{NH} 4}$ & $F_{\mathrm{HPO} 4}$ & $F_{\mathrm{Si}}$ & $F_{\mathrm{N} 2 \mathrm{O}}$ \\
\hline $\mathrm{BC} 1$ & 17 Jun 06 & $0.15 \pm 0.06$ & $0.15 \pm 0.03$ & $0.65 \pm 0.20$ & $0.07 \pm 0.02$ & $1.02 \pm 0.09$ & $10.4 \pm 5.6$ \\
\hline $\mathrm{BC} 2$ & 18 Jun 06 & $0.02 \pm 0.02$ & $0.09 \pm 0.02$ & $3.10 \pm 0.13$ & $0.22 \pm 0.05$ & $2.87 \pm 0.20$ & $7.24 \pm 3.5$ \\
\hline $\mathrm{BC} 3$ & 19 Jun 06 & $0.23 \pm 0.07$ & $-0.09 \pm 0.04$ & $-0.33 \pm 0.10$ & $-0.04 \pm 0.01$ & $1.06 \pm 0.13$ & $-1.2 \pm 0.6$ \\
\hline $\mathrm{BC} 4$ & 20 Jun 06 & $0.10 \pm 0.05$ & $\mathrm{~nm}$ & $1.57 \pm 0.37$ & $0.05 \pm 0.02$ & $2.55 \pm 0.23$ & $9.1 \pm 2.4$ \\
\hline BC5 & 21 Jun 06 & $0.22 \pm 0.02$ & $0.10 \pm 0.02$ & $2.00 \pm 0.38$ & $0.11 \pm 0.03$ & $2.13 \pm 0.16$ & $3.8 \pm 0.6$ \\
\hline GL2 & 24 Jun 06 & $0.23 \pm 0.11$ & $0.03 \pm 0.01$ & $2.37 \pm 0.33$ & $0.20 \pm 0.02$ & $0.84 \pm 0.16$ & $3.5 \pm 1.3$ \\
\hline GL3 & 26 Jun 06 & $-0.16 \pm 0.05$ & $-0.08 \pm 0.03$ & $0.96 \pm 0.43$ & $0.22 \pm 0.11$ & $0.95 \pm 0.17$ & $3.2 \pm 1.1$ \\
\hline GL4 & 27 Jun 06 & $-0.21 \pm 0.07$ & $-0.12 \pm 0.09$ & $1.63 \pm 0.30$ & $\mathrm{~nm}$ & $0.12 \pm 0.47$ & $3.6 \pm 3.0$ \\
\hline $\mathrm{BC} 1$ & 19 Nov 06 & $0.86 \pm 0.18$ & $-0.07 \pm 0.02$ & $0.58 \pm 0.15$ & $0.10 \pm 0.01$ & $0.96 \pm 0.11$ & $6.9 \pm 3.3$ \\
\hline $\mathrm{BC} 2$ & 20 Nov 06 & $0.97 \pm 0.14$ & $0.05 \pm 0.03$ & $0.49 \pm 0.32$ & $0.05 \pm 0.02$ & $1.24 \pm 0.16$ & $7.3 \pm 1.4$ \\
\hline $\mathrm{BC} 3$ & 21 Nov 06 & $0.38 \pm 0.06$ & $0.15 \pm 0.06$ & $0.77 \pm 0.27$ & $\mathrm{~nm}$ & $1.08 \pm 0.11$ & $9.4 \pm 3.7$ \\
\hline $\mathrm{BC} 4$ & 22 Nov 06 & $-0.57 \pm 0.17$ & $-0.13 \pm 0.03$ & $0.20 \pm 0.11$ & $\mathrm{~nm}$ & $0.21 \pm 0.07$ & $9.7 \pm 0.8$ \\
\hline BC5 & 23 Nov 06 & $0.36 \pm 0.17$ & $-0.04 \pm 0.01$ & $1.95 \pm 0.48$ & $0.11 \pm 0.01$ & $1.46 \pm 0.44$ & $10.1 \pm 0.2$ \\
\hline GL1 & 29 Nov 06 & $0.18 \pm 0.06$ & $0.07 \pm 0.01$ & $1.89 \pm 0.29$ & $0.15 \pm 0.03$ & $1.67 \pm 0.26$ & $7.9 \pm 11.6$ \\
\hline GL2 & 28 Nov 06 & $0.33 \pm 0.04$ & $0.15 \pm 0.05$ & $2.31 \pm 0.47$ & $0.11 \pm 0.01$ & $1.68 \pm 0.21$ & $2.5 \pm 0.4$ \\
\hline GL3 & 27 Nov 06 & $0.50 \pm 0.12$ & $0.07 \pm 0.05$ & $1.57 \pm 0.12$ & $0.05 \pm 0.01$ & $0.47 \pm 0.07$ & $3.7 \pm 1.8$ \\
\hline GL4 & 26 Nov 06 & $0.29 \pm 0.07$ & $0.10 \pm 0.02$ & $0.80 \pm 0.17$ & $-0.04 \pm 0.01$ & $2.14 \pm 0.45$ & $3.0 \pm 2.5$ \\
\hline BC1 & 31 Jan 07 & $0.64 \pm 0.18$ & $0.26 \pm 0.06$ & $1.52 \pm 0.38$ & $0.20 \pm 0.061$ & $0.82 \pm 0.13$ & $2.2 \pm 1.1$ \\
\hline $\mathrm{BC} 2$ & 01 Feb 07 & $0.15 \pm 0.05$ & $-0.25 \pm 0.03$ & $-0.87 \pm 0.21$ & $-0.03 \pm 0.003$ & $0.48 \pm 0.11$ & $3.3 \pm 0.3$ \\
\hline $\mathrm{BC} 3$ & 02 Feb 07 & $0.13 \pm 0.02$ & $-0.04 \pm 0.01$ & $0.85 \pm 0.25$ & $0.05 \pm 0.014$ & $1.09 \pm 0.13$ & $2.1 \pm 0.7$ \\
\hline $\mathrm{BC} 4$ & 03 Feb 07 & $0.08 \pm 0.04$ & $0.05 \pm 0.01$ & $1.22 \pm 0.33$ & $0.01 \pm 0.001$ & $0.78 \pm 0.10$ & $3.3 \pm 0.6$ \\
\hline BC5 & 04 Feb 07 & $\mathrm{~nm}$ & $-0.06 \pm 0.02$ & $-1.21 \pm 0.13$ & $0.02 \pm 0.014$ & $0.52 \pm 0.07$ & $1.7 \pm 0.9$ \\
\hline GL1 & 06 Feb 07 & $-0.86 \pm 0.41$ & $-0.07 \pm 0.02$ & $3.50 \pm 0.97$ & $-0.02 \pm 0.008$ & $2.22 \pm 0.58$ & $3.1 \pm 0.6$ \\
\hline GL2 & 07 Feb 07 & $0.38 \pm 0.03$ & $0.03 \pm 0.01$ & $0.42 \pm 0.09$ & $0.06 \pm 0.013$ & $1.38 \pm 0.10$ & $0.7 \pm 0.1$ \\
\hline GL3 & 08 Feb 07 & $0.17 \pm 0.02$ & $-0.05 \pm 0.01$ & $1.48 \pm 0.14$ & $0.02 \pm 0.006$ & $1.60 \pm 0.29$ & $1.3 \pm 0.6$ \\
\hline
\end{tabular}

directed in opposite directions. Ammonium fluxes, ranging from -0.33 to $3.10 \mathrm{mmol} \mathrm{m}^{-2} \mathrm{~d}^{-1}$, were always positive except for 3 occasions in $\mathrm{BC}$ sites. Benthic fluxes of $\mathrm{NO}_{3}{ }^{-}, \mathrm{NO}_{2}{ }^{-}$, and $\mathrm{NH}_{4}{ }^{+}$did not differ significantly between BC and GL regions or among seasons. Seasonally averaged $\mathrm{NO}_{3}{ }^{-}$and $\mathrm{NH}_{4}{ }^{+}$fluxes at each site showed a significant linear correlation with the organic carbon content of surface sediments, which was negative for the former $\left(\mathrm{r}^{2}=0.47\right)$ and positive for the latter $\left(r^{2}=0.74\right)$. In contrast to nitrate fluxes, seasonally averaged $\mathrm{NH}_{4}^{+}$fluxes also correlated with average carbon oxidation rates for each site $\left(r^{2}=0.72\right)$.

Nitrous oxide fluxes were very variable and directed out of the sediments, except for 1 deployment in June 2006 at $\mathrm{BC} 3$, which also coincided with a sediment uptake of $\mathrm{NO}_{3}{ }^{-}, \mathrm{NO}_{2}{ }^{-}$, and $\mathrm{NH}_{4}{ }^{+}$. Nitrous oxide fluxes ranged from -1.2 to $10.4 \mu \mathrm{mol} N-\mathrm{N}_{2} \mathrm{O} \mathrm{m} \mathrm{m}^{-2} \mathrm{~d}^{-1}$ and accounted on average for less than $1 \%$ of benthic inorganic nitrogen fluxes $\left(\mathrm{NO}_{3}{ }^{-}+\mathrm{NO}_{2}{ }^{-}+\mathrm{NH}_{4}{ }^{+}\right)$. The ratio of $\mathrm{N}_{2} \mathrm{O}$ fluxes to total inorganic nitrogen fluxes varied significantly among the 3 sampled seasons ( $p<0.05)$, being highest in June 2006 and lowest in February 2007. Nitrous oxide fluxes were significantly smaller in February 2007 than in November 2006 ( $\mathrm{p}<0.01$ ), and no significant differences were observed between GL and BC sites.
$\mathrm{HPO}_{4}{ }^{2-}$ was normally released to the water column with the exception of a few cases in which it was taken up by the sediment. Benthic $\mathrm{HPO}_{4}{ }^{2-}$ fluxes, ranging from -0.04 to $0.22 \mathrm{mmol} \mathrm{m}^{-2} \mathrm{~d}^{-1}$, were variable and did not show any clear spatial or temporal trends.

$\mathrm{Si}(\mathrm{OH})_{4}$ fluxes ranged from 0.21 to $2.87 \mathrm{mmol} \mathrm{m}^{-2} \mathrm{~d}^{-1}$ and did not differ significantly between BC and GL sites or among seasons. Seasonally averaged $\mathrm{Si}(\mathrm{OH})_{4}$ fluxes were linearly correlated with average carbon oxidation rates $\left(\mathrm{r}^{2}=0.65\right)$ and sediment surface organic carbon $\left(\mathrm{r}^{2}=0.65\right)$.

\section{Factors controlling benthic organic matter mineralization and nutrient recycling}

The relationships among sediment and bottom water properties and benthic fluxes were analyzed using PCA to elucidate the primary factors driving benthic organic matter mineralization and nutrient recycling in the northeastern shelf of the Gulf of Cádiz (Table 3). Component 1 was indicative of organic matter mineralization $\left(\mathrm{C}_{\mathrm{ox}}\right)$, concomitant with ammonium and silicate effluxes, and it was significantly associated with the content of organic carbon and median grain size of surface sediments. Component 2 was positively associ- 
Table 3. Principal components analysis of sediment and bottom water properties and benthic fluxes for the northeastern shelf of the Gulf of Cádiz. Associations of parameters with a component are considered significant if the score is $>0.5$ (in bold)

\begin{tabular}{|c|c|c|c|c|}
\hline & 1 & 2 & 3 & 4 \\
\hline $\mathrm{C}_{\mathrm{OX}}$ & 0.90 & 0.10 & 0.11 & 0.04 \\
\hline$F_{\mathrm{NH} 4}$ & 0.81 & 0.32 & -0.03 & -0.03 \\
\hline$F_{\mathrm{NO} 3}$ & -0.47 & 0.62 & -0.12 & 0.31 \\
\hline$F_{\mathrm{NO} 2}$ & 0.06 & 0.80 & 0.05 & -0.11 \\
\hline$F_{\mathrm{HPO} 4}$ & 0.22 & 0.76 & 0.07 & 0.16 \\
\hline$F_{\mathrm{Si}}$ & 0.74 & 0.23 & 0.30 & -0.01 \\
\hline $\mathrm{OC}$ & 0.84 & -0.28 & -0.15 & 0.08 \\
\hline C:N & -0.40 & -0.15 & 0.19 & 0.41 \\
\hline$D_{50}$ & -0.71 & 0.27 & 0.07 & -0.54 \\
\hline Biomass & 0.16 & 0.01 & 0.09 & 0.86 \\
\hline Abundance & -0.01 & 0.04 & 0.10 & 0.95 \\
\hline Oxygen & -0.04 & -0.65 & -0.18 & 0.36 \\
\hline $\mathrm{NO}_{3}^{-}$ & -0.05 & -0.20 & -0.90 & -0.07 \\
\hline Salinity & 0.06 & 0.26 & 0.81 & 0.06 \\
\hline Temperature & -0.04 & -0.32 & 0.89 & 0.12 \\
\hline$\%$ of variance & 25.6 & 18.8 & 17.5 & 12.6 \\
\hline
\end{tabular}

ated with benthic fluxes of phosphate, nitrate, and nitrite, and negatively correlated to bottom water oxygen concentration. Component 3 indicated a negative relationship between bottom water nitrate concentrations and both temperature and salinity. Finally, component 4 was positively associated with the abundance and biomass of macrofauna, which were mostly correlated (negative) to sediment grain size. The 4 components explained $74.5 \%$ of the data variability.

\section{Denitrification and nitrification rates}

The molar ratios of mineralized carbon to the flux of inorganic nitrogen (nitrate + nitrite + ammonium) $\left(\mathrm{C}_{\mathrm{ox}}: F_{\mathrm{IN}}\right)$ can be used to investigate the preferential pathways of organic matter remineralization, given the $\mathrm{C}: \mathrm{N}$ ratio of deposited organic matter. The C:N:P Redfield ratio (106:16:1) is often applied to compare it to measured solute flux ratios, considering that only phytoplanktonderived material is undergoing diagenesis (Berelson et al. 1998, 2003, Jahnke \& Jahnke 2000). However, the organic matter in the study site is likely affected by terrestrial or seagrass detritus, which is expected to have higher C:N ratios (e.g. Enriquez et al. 1993).

Measured fluxes of inorganic nitrogen $\left(\mathrm{NO}_{3}{ }^{-}+\mathrm{NO}_{2}{ }^{-}\right.$ $+\mathrm{NH}_{4}{ }^{+}$) were in general lower than those expected from benthic mineralization when assuming in 1 case the Redfield and in the other case the sediment $\mathrm{C}: \mathrm{N}$ ratios for organic matter (Fig. 4a,b). Average denitrification rates for each site, calculated applying Eq. (1), ranged from 1.12 to $3.74 \mathrm{mmol} \mathrm{N} \mathrm{m}^{-2} \mathrm{~d}^{-1}$, assuming a Redfield stoichiometry for mineralized organic matter,
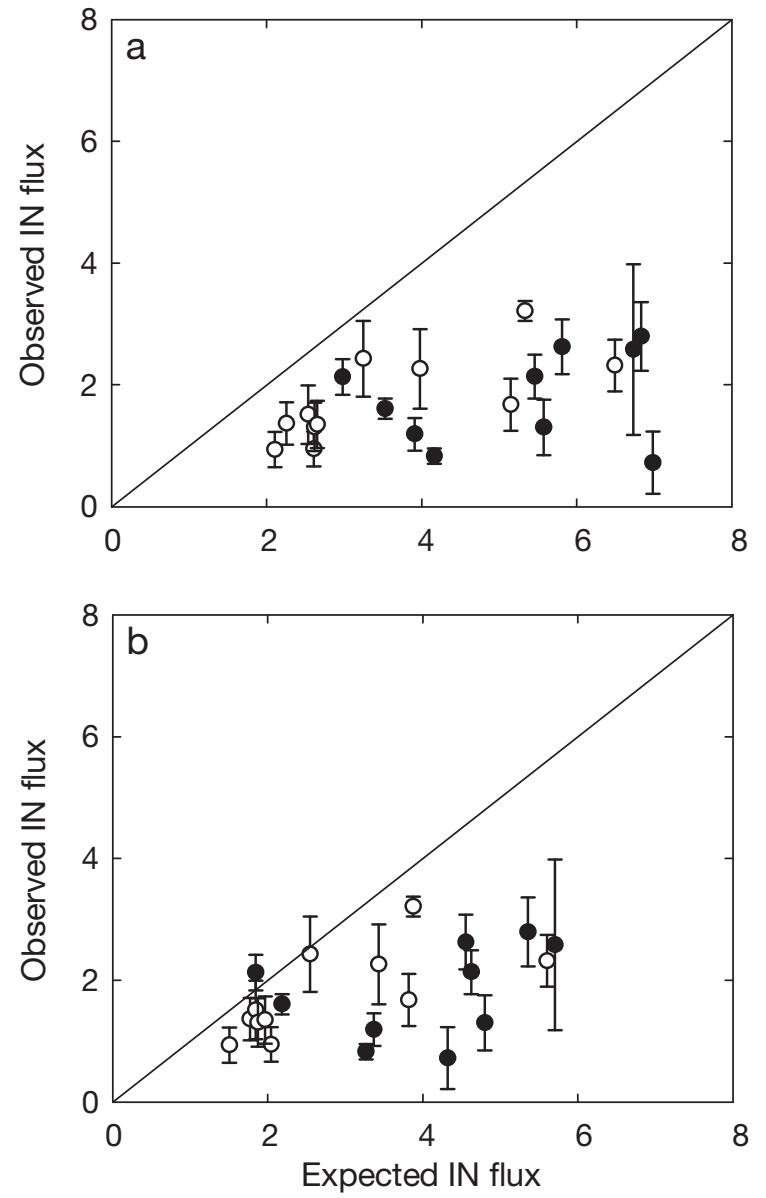

Fig. 4. Measured fluxes of inorganic nitrogen vs. expected fluxes derived from carbon oxidation rates (a) assuming Redfield stoichiometry; (b) assuming sediment C:N ratio for organic matter. White and black symbols represent BC and GL sites, respectively. The lines represent the 1:1 relationship. Fluxes are in $\mathrm{mmol} \mathrm{N} \mathrm{m}{ }^{-2} \mathrm{~d}^{-1}$

and from 0.61 to $3.23 \mathrm{mmol} \mathrm{N} \mathrm{m}^{-2} \mathrm{~d}^{-1}$, assuming observed sediment C:N molar ratios (Table 4). The ratio of denitrification rates based on Redfield stoichiometry to those based on sediment $\mathrm{C}: \mathrm{N}$ ratios was on average 1.7, which demonstrates the sensitivity of these calculations to the $\mathrm{C}: \mathrm{N}$ ratio of mineralized organic matter. Averaged carbon remineralization rates attributed to denitrification ranged from 8 to $15 \%$ considering Redfield stoichiometry, and from 4 to $14 \%$ considering sediment $\mathrm{C}: \mathrm{N}$ ratios.

Average nitrification rates calculated from Eq. (3) ranged from 1.79 to $3.90 \mathrm{mmol} \mathrm{N} \mathrm{m}^{-2} \mathrm{~d}^{-1}$ and from 1.27 to $3.42 \mathrm{mmol} \mathrm{N} \mathrm{m}^{-2} \mathrm{~d}^{-1}$, applying Redfield and observed sediment C:N ratio, respectively (Table 4). These rates were on average between 1.2 and 1.5 times higher than denitrification rates. The ratio of nitrification rates based on Redfield stoichiometry to the ones based on sediment $\mathrm{C}: \mathrm{N}$ ratios was on average 1.5. Estimated denitrification and nitrification rates did 
Table 4. Average carbon mineralization rates $\left(\mathrm{C}_{\text {oxi }}\right.$ mmol $\left.\mathrm{C} \mathrm{m}^{-2} \mathrm{~d}^{-1}\right)$, nitrification rates $\left(F_{\text {niti }} \mathrm{mmol} \mathrm{N} \mathrm{m}^{-2} \mathrm{~d}^{-1}\right)$, denitrification rates

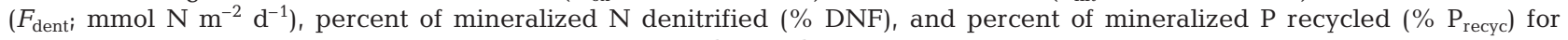
each sampling site

\begin{tabular}{|c|c|c|c|c|c|c|c|c|}
\hline Site & $\mathrm{C}_{\mathrm{ox}}{ }^{\mathrm{a}}$ & $F_{\text {nit }}^{b}$ & $F_{\text {nit }}{ }^{\mathrm{c}}$ & $F_{\text {dent }}{ }^{b}$ & $F_{\text {dent }}{ }^{c}$ & $\% \mathrm{DNF}^{\mathrm{b}}$ & $\% \mathrm{DNF}^{\mathrm{c}}$ & $\% \mathrm{P}_{\text {recyc }}{ }^{\mathrm{b}}$ \\
\hline BC1 & 17.9 & 1.79 & 1.27 & 1.12 & 0.61 & 42.7 & 29.2 & 71.7 \\
\hline $\mathrm{BC} 2$ & 23.1 & 2.57 & 1.71 & 2.23 & 1.37 & 72.6 & 63.6 & 26.5 \\
\hline BC3 & 18.4 & 2.34 & 1.76 & 2.24 & 1.66 & 74.5 & 67.8 & 28.7 \\
\hline $\mathrm{BC} 4$ & 24.2 & 2.66 & 1.75 & 2.81 & 1.90 & 77.4 & 69.9 & 10.1 \\
\hline BC5 & 28.9 & 3.69 & 3.42 & 3.50 & 3.23 & 81.9 & 80.8 & 26.6 \\
\hline Mean $\pm \mathrm{SD}$ & $22.8 \pm 5.1$ & $2.6 \pm 0.7$ & $2.0 \pm 0.8$ & $2.4 \pm 0.9$ & $1.8 \pm 1.0$ & $70 \pm 16$ & $62 \pm 20$ & $33 \pm 23$ \\
\hline GL1 & 40.4 & 3.40 & 2.45 & 3.74 & 2.78 & 61.3 & 54.1 & 19.6 \\
\hline GL2 & 37.1 & 3.90 & 2.69 & 3.52 & 2.31 & 64.6 & 54.9 & 34.3 \\
\hline GL3 & 29.8 & 3.16 & 1.82 & 3.01 & 1.67 & 57.5 & 39.4 & 29.6 \\
\hline GL4 & 31.4 & 3.53 & 2.88 & 3.50 & 2.84 & 73.1 & 68.8 & -16.4 \\
\hline Mean \pm SD & $34.7 \pm 4.9$ & $3.5 \pm 0.3$ & $2.5 \pm 0.5$ & $3.4 \pm 0.3$ & $2.4 \pm 0.5$ & $64 \pm 7$ & $54 \pm 12$ & $17 \pm 23$ \\
\hline
\end{tabular}

not vary significantly among the seasons or between $\mathrm{BC}$ and GL regions, although they were considerably smaller in BC1 compared to the other stations.

\section{$P$ recycling efficiency}

Averaged for each site, P recycling efficiencies, which account for the average fraction of remineralized $\mathrm{P}$ that is recycled to the water column, were very variable and ranged from $-8 \%$ (net uptake) at GL4 to $72 \%$ at $\mathrm{BC} 1$. Average $\mathrm{P}$ recycling efficiencies were negatively correlated to the water depth, with the best fit being logarithmic $\left(\% \mathrm{P}_{\text {recyc }}=-37.4 \operatorname{Ln}[z]+\right.$ $\left.137.2 ; \mathrm{r}^{2}=0.65\right)$.

\section{DISCUSSION}

\section{$\mathbf{N}$ regeneration}

In marine sediments there are 3 principal microbial processes that affect $\mathrm{N}$ regeneration: denitrification, nitrification, and ammonification, i.e. the release of $\mathrm{NH}_{4}{ }^{+}$from organic matter (Bronk \& Steinberg 2008). Denitrification is of particular interest in coastal systems because it represents a net loss of $\mathrm{N}$ (as $\mathrm{N}_{2}$ ) and, therefore, reduces the $\mathrm{N}$-enrichment in these environments (Devol 2008). Apart from the classical denitrification process, the recently discovered anaerobic ammonium oxidation with nitrite (anammox) can also be involved in benthic production of $\mathrm{N}_{2}$ (Thamdrup \& Dalsgaard 2002). The most important drivers controlling the relative importance of anammox in sediment $\mathrm{N}_{2}$ production are water depth (and hence benthic mineralization rates) and $\mathrm{NO}_{3}{ }^{-}$availability (Thamdrup \& Dalsgaard 2002, Dalsgaard et al. 2005). According to these authors, the relative contribution of this route to $\mathrm{N}_{2}$ production is often less than $20 \%$ in shallow sediments $(<50 \mathrm{~m})$ with the highest $\mathrm{N}_{2}$ production in environments with high $\mathrm{NO}_{3}{ }^{-}$availability. Thus, given the shallowness and very low nitrate levels of the study site, we have assumed that denitrification is the main $\mathrm{N}_{2}$-producing process. In addition, the anaerobic dissimilatory nitrate reduction to ammonium (DNRA) can also be involved in the sedimentary $\mathrm{N}$ cycle, although this route is generally only significant in organic rich sediments with high free sulfide concentrations, such as estuarine sediments (Rysgaard et al. 1996) and under fish culture net pens (Christensen et al. 2000).

Benthic $\mathrm{NH}_{4}{ }^{+}$fluxes measured in the northeastern shelf of the Gulf of Cádiz were within the range reported for coastal environments (Berelson et al. 1998, 2003, Hopkinson et al. 2001, Bronk \& Steinberg 2008 and references therein). The regeneration of $\mathrm{NH}_{4}{ }^{+}$was related to benthic organic matter remineralization, which at the study site was found to be mainly controlled by the organic matter content in surface sediments (Table 3, Ferrón et al. unpubl.). Although this pattern has been previously observed (e.g. Forja et al. 2004, Lansard et al. 2008), other authors have found that benthic remineralization is mainly controlled by the quality, rather than the quantity, of sedimentary organic matter (Arnosti \& Holmer 2003, Ståhl et al. 2004a). Although not significantly, component 1 of the PCA was negatively associated with surface sediment $\mathrm{C}: \mathrm{N}$ ratios, which are considered to be indicative of organic matter quality. However, the stronger contribution of bulk sediment organic carbon to component 1, together with the significant relationships observed 
between $\mathrm{Si}(\mathrm{OH})_{4}$ benthic fluxes and both organic carbon oxidation rates and organic carbon content in surface sediments, seemed to indicate that a considerable fraction of the latter must be labile (e.g. fresh diatoms).

Contrary to $\mathrm{NH}_{4}{ }^{+}$fluxes, $\mathrm{NO}_{3}{ }^{-}$fluxes were negatively correlated to component 1 . In addition, benthic fluxes of $\mathrm{NO}_{3}{ }^{-}$and $\mathrm{NO}_{2}{ }^{-}$, which were within the range reported for other coastal environments (Berelson et al. 1998, 2003, Hopkinson et al. 2001, Bronk \& Steinberg 2008 and references therein), were negatively correlated to bottom water oxygen concentration (component 2). In fact, oxygen strongly affects most of the processes involved in the $\mathrm{N}$ cycle, with the exception of organic $\mathrm{N}$ mineralization or $\mathrm{NH}_{4}{ }^{+}$regeneration, which occurs under both oxic and anoxic conditions (Joye \& Anderson 2008). The lower and upper limits for denitrification rates estimated for the study site, assuming that denitrification was the main $\mathrm{N}_{2}$-producing process, indicated that on average between 60 and $68 \%$ of the nitrogen mineralized was denitrified, respectively. This is in good agreement with other values reported in the literature for marine sediments (Seitzinger 1988, Seitzinger \& Giblin 1996, Berelson et al. 1998, Jahnke \& Jahnke 2000, Hopkinson et al. 2001, Laursen \& Seitzinger 2002). Average denitrification rates for each sampling site were linearly correlated to surface sediment organic carbon and carbon oxidation rates. Taking into account the lower and upper limits calculated for denitrification rates, it was estimated that this process contributed between 9 and $13 \%$ to total organic matter oxidation. Laursen \& Seitzinger (2002) found a similar contribution in continental shelf sediments of the MidAtlantic Bight, where denitrification accounted for $13 \%$ of total benthic remineralization.

In general, sediments acted as a source of $\mathrm{N}_{2} \mathrm{O}$ to the water column, and measured fluxes were in the range of those reported in other coastal environments (Seitzinger 1988, Hopkinson et al. 2001, Laursen \& Seitzinger 2002). In marine sediments, $\mathrm{N}_{2} \mathrm{O}$ is mainly produced by denitrification, nitrification, nitrifier-denitrification, and DNRA. Although $\mathrm{N}_{2} \mathrm{O}$ benthic fluxes were negligible in terms of mineralized $\mathrm{N}$, representing on average less than $1 \%$ of measured inorganic $\mathrm{N}$ fluxes $\left(\mathrm{NH}_{4}{ }^{+}+\mathrm{NO}_{3}{ }^{-}+\right.$ $\mathrm{NO}_{2}{ }^{-}$), they may represent a significant source of $\mathrm{N}_{2} \mathrm{O}$ to the water column. In this sense, averaged for each season and region (BC and GL), bottom water $\mathrm{N}_{2} \mathrm{O}$ concentrations significantly correlated with $\mathrm{N}_{2} \mathrm{O}$ benthic fluxes, with the best fit being a second order polynomial $\left(\mathrm{r}^{2}=0.83\right)$.

\section{$P$ regeneration}

$\mathrm{HPO}_{4}{ }^{2-}$ fluxes were in good agreement with those measured in other coastal environments (Berelson et

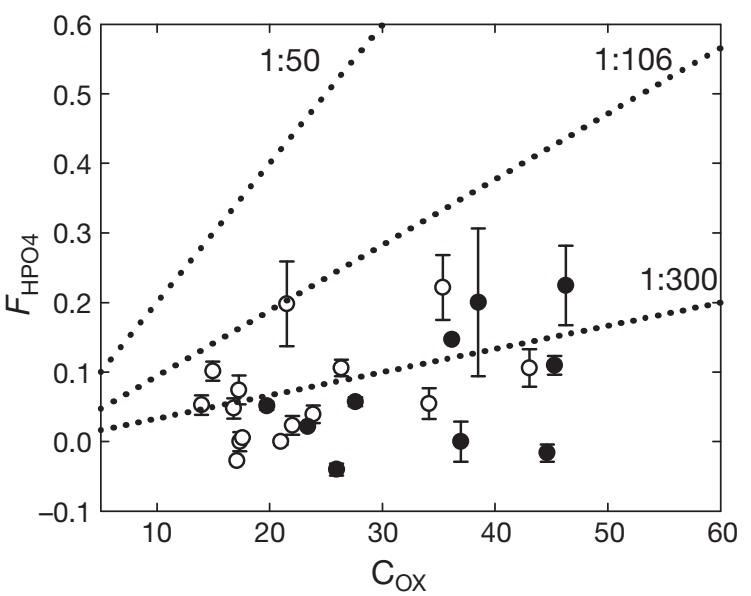

Fig. 5. Measured $\mathrm{HPO}_{4}{ }^{2-}$ fluxes vs. organic carbon oxidation rates. Open and filled symbols represent BC and GL sites, respectively. The dotted lines represent the indicated P:C molar ratios or remineralized organic matter. Units are in $\mathrm{mmol} \mathrm{m}{ }^{-2} \mathrm{~d}^{-1}$

al. 1998, 2003, Hopkinson et al. 2001) and were poorly correlated with carbon remineralization rates, indicating that there must be other sources and sinks for $\mathrm{P}$ (Fig. 5). Flux ratio lines of 1:106 (Redfield ratio), 1:50, and 1:300 $\left(F_{\mathrm{P}}: \mathrm{C}_{\mathrm{OX}}\right)$ are plotted in Fig. 5 as a reference, as $\mathrm{P}: \mathrm{C}$ ratios of mineralized organic matter may deviate from Redfield stoichiometry. Measured benthic $\mathrm{HPO}_{4}{ }^{2-}$ fluxes were in all cases lower than expected from carbon mineralization rates and Redfield stoichiometry, and also often lower than expected from organic matter with lower $\mathrm{P}: \mathrm{C}$ ratios. On the other hand, the PCA showed a significant negative relationship between benthic $\mathrm{HPO}_{4}{ }^{2-}$ fluxes and bottom water oxygen concentrations (component 2). In this context, lower $F_{\mathrm{p}}: \mathrm{C}_{\mathrm{OX}}$ ratios are often reported in the literature for oxic environments, whereas higher ratios are found in areas with oxygen-depleted bottom waters (e.g. Ingall \& Jahnke 1997, McManus et al. 1997). This is further corroborated by the negative linear relationship found between estimated P recycling efficiencies and oxygen concentrations in bottom water $\left(\mathrm{r}^{2}=0.51\right.$; only efficiencies $>0 \%$ considered in the fit). The efflux of remineralized phosphate may be controlled in the surface oxidized layer by sorption with iron oxyhydroxides (Patrick \& Khalid 1974). In a nearby shallow tidal creek located within the saltmarsh area of the Bay of Cádiz (Río San Pedro), Ferrón et al. (2009) reported $\mathrm{HPO}_{4}{ }^{2-}$ benthic fluxes ranging from 0.2 to $2.4 \mathrm{mmol}$ $\mathrm{m}^{-2} \mathrm{~d}^{-1}$, and they associated the high $\mathrm{P}$ recycling efficiencies observed (mostly in the summer) to the low oxygen concentrations in the water column, as well to the release of inorganic mineral $\mathrm{P}$ adsorbed into the sediments. At the study site, where relatively high bottom water oxygen concentrations were observed, and 
taking into account the low $\left(F_{\mathrm{p}}\right.$ : $\left.\mathrm{C}_{\mathrm{Ox}}\right)$ ratios found, a considerable fraction of the $\mathrm{P}$ mineralized is likely being retained in the sediments by adsorption or mineral precipitation. In addition, the magnitude of $\mathrm{P}$ regenerated to the water column seemed to be mainly driven by bottom water oxygen concentration and water column depth, rather than by the total rate of organic matter mineralization.

\section{Influence of macrofauna on nutrient regeneration}

It is well documented that the presence of meio- and macrofauna affects benthic mineralization and nutrient recycling through feeding, burrowing, and irrigating (Aller 1982, Aller \& Aller 1998). Due to the large sediment surface covered by the chamber used in this study, measured benthic fluxes already integrate the influence of macrofauna on benthic carbon remineralization and nutrient regeneration. Sediment bioturbation, burrowing, and irrigation affect the vertical distribution of organic matter within sediments, increase exposure of sediment to oxygen, enhance the exchange of solutes between sediment and overlying water, and, therefore, influence a variety of aerobic and anaerobic microbial processes (Aller 1982, Aller \& Aller 1998). In shallow nearby sediments of the Bay of Cádiz, Forja \& Gómez-Parra (1998) found that macrofauna affected the top 10 to $15 \mathrm{~cm}$ of sediment, significantly enhancing benthic fluxes of inorganic carbon and nutrients. However, the PCA failed to show any significant relationship between total macrofaunal abundance or biomass and organic matter mineralization and nutrient benthic fluxes. This was also true when separated into the different classes or the different trophic groups. The PCA showed that macrofaunal abundance and biomass correlated with component 4 (Table 3), and that both variables were negatively correlated to the median sediment grain size. No trends were observed between macrofaunal community and organic carbon content in surface sediments. Similarly, previous investigations in the northern Aegean Sea and the Skagerrak (NE North Sea) showed no correlation between macrofaunal biomass and organic carbon oxidation rates (Ståhl et al. 2004a,b). However, in Skagerrat sediments, measured dissolved inorganic carbon fluxes were enhanced by 1.0 to 5.4 times over diffusive fluxes, indicating that macrofauna had a significant effect on benthic exchange rates of organic carbon remineralization products (Ståhl et al. 2004a,b). The lack of correlation between macrofauna abundance or biomass and carbon oxidation rates may partly be explained by the existence of patchiness in the macrofaunal communities, as well as the complexity of assessing the species-specific traits and func- tional biodiversity. In this sense, the overall indirect enhancement of bacterial respiration rates by bioirrigation and bioturbation activities depends on several factors such as the structure of the macrobenthic community, the size distribution, the geometrical shape of burrows, and the modes of burrow ventilation and feeding strategies (Aller \& Yingst 1978). Therefore, macrofaunal biomass or abundance my not be sensitive measures of macrofaunal influence on benthic remineralization rates (Ståhl et al. 2004a). Furthermore, macrofauna in this study was only sampled in November 2006 and, hence, data may not be sufficient to establish any correlation with other parameters measured in this study.

In addition to macrofauna, the presence of benthic microalgae has a significant effect in sediment biogeochemistry and nutrient cycling (Jahnke 2005). This has been clearly demonstrated in shallow littoral sediments $(<2 \mathrm{~m})$ that present lower sediment-water $\mathrm{NH}_{4}{ }^{+}$fluxes than deeper sediments (Joye \& Anderson 2008), suggesting an autotrophic uptake at shallower depths. However, some authors have observed significant benthic primary production rates in continental shelf sediments (e.g. Hopkinson et al. 1991, Jahnke et al. 2000). It is estimated that up to $30 \%$ of the continental shelf sea floor could receive enough light to support significant rates of benthic photosynthesis (Jahnke 2005). If that were the case, the exclusion of sunlight by the chambers would prevent benthic primary production reducing sediment oxygen penetration depth and, thereby, nitrification-denitrification potential and phosphate binding capacity. Consequently, our data would not integrate net metabolism but only respiration.

\section{Role of benthic remineralization and nutrient recycling}

Based on net primary production measurements performed in nearby stations of the Gulf of Cádiz using the ${ }^{14} \mathrm{C}$ uptake method (Huertas et al. 2005, Navarro et al. 2006), it is possible to examine the importance of benthic carbon remineralization on the fertilization of the system. An average integrated primary production value of about $700 \mathrm{mg} \mathrm{C} \mathrm{m}^{-2} \mathrm{~d}^{-1}$ was assumed, which is the average of the values reported by Navarro et al. (2006) for the most coastal stations. Given the annually averaged carbon oxidation rate for the study site $(28 \pm$ $8 \mathrm{mmol} \mathrm{C} \mathrm{m} \mathrm{C} \mathrm{d}^{-1}$ ), benthic remineralization degrades about $47 \%$ of net primary production (Fig. 6). The dependence of carbon remineralization rates on surface sediment organic carbon reported throughout the study site, together with the significance of sediments in degrading primary produced organic matter, seem 

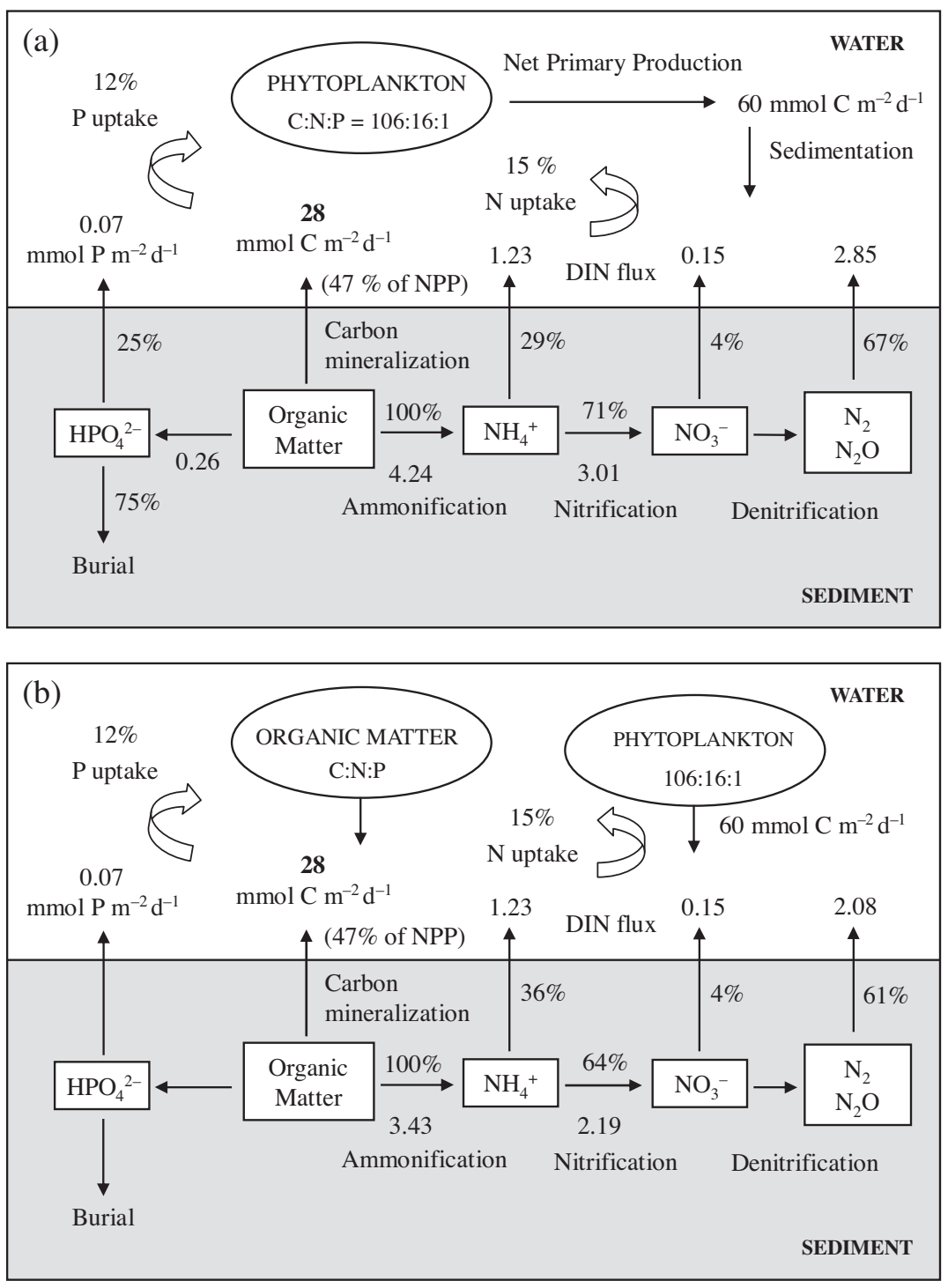

Fig. 6. $\mathrm{N}$ cycle for the northeastern shelf of the Gulf of Cádiz. Units are in mmol $\mathrm{N} \mathrm{m}^{-2} \mathrm{~d}^{-1}$, except for net primary production (NPP) and $\mathrm{C}$ mineralization, which are in $\mathrm{mmol} \mathrm{C} \mathrm{m} \mathrm{m}^{-2} \mathrm{~d}^{-1}$. Also shown are the percentages of $\mathrm{N}$ remineralized under the different pathways, the percentage of primary produced $\mathrm{C}$ remineralized in the sediments, and the percentage of phytoplankton required $\mathrm{N}$ supplied by benthic recycling (a) assuming Redfield stoichiometry; (b) assuming sediment C:N ratio for organic matter

to indicate a tight benthic-pelagic coupling in this system (Fig. 6). Moreover, based on measured average fluxes of inorganic nitrogen $\left(\mathrm{NO}_{3}{ }^{-}+\mathrm{NO}_{2}{ }^{-}+\mathrm{NH}_{4}{ }^{+}\right)$and $\mathrm{HPO}_{4}{ }^{2-}$, benthic nutrient recycling supplied about $15 \%$ and $12 \%$, respectively, of total nitrogen and phosphorus phytoplankton requirements to the water column. The remaining $\mathrm{N}$ and $\mathrm{P}$ required by phytoplankton are very likely supplied by terrestrial inputs and upwelling events. The significance of benthic carbon remineralization and nutrient regeneration in these shelf sediments seems to be relatively high. For example, Hopkinson et al. (2001) found that benthic metab- olism was equivalent to 20 to $24 \%$ and 11 to $14 \%$ of the primary production in Massachusetts Bay (30 $\mathrm{m}$ deep) and Stellwagen Bay (75 m deep), respectively. In the same study, these authors reported that benthic remineralization supplied 3 to $8 \%$ of the $\mathrm{N}$ and 11 to $15 \%$ of the $\mathrm{P}$ required for phytoplankton primary production in those coastal systems.

Two different average budgets for the $\mathrm{N}$ cycle have been estimated for the study site depending on our assumption about the C:N of organic matter undergoing decomposition: based on Redfield ratio or based on bulk sediment C:N ratio (Fig. 6a \& b, respectively). For 
P, only the Redfield assumption was available. Overall, between 29 and $36 \%$ of total mineralized nitrogen was released to the water column as $\mathrm{NH}_{4}{ }^{+}$, whereas a small fraction $(\sim 4 \%)$ was released as $\mathrm{NO}_{3}{ }^{-}$. Between 61 and $67 \%$ of total mineralized nitrogen was estimated to be lost via denitrification. If this fraction of mineralized $\mathrm{N}$ was returned to the water column as bioavailable dissolved inorganic nitrogen instead of lost as $\mathrm{N}_{2}$, it could support an additional $\sim 14$ to $19 \mathrm{mmol} \mathrm{C} \mathrm{m} \mathrm{C} \mathrm{d}^{-1}$ of phytoplankton production. Therefore, even if these sediments seemed to recycle a considerable fraction of the $\mathrm{N}$ required by phytoplankton, they represent a net loss of total nitrogen for this environment. In comparison, in Mid-Atlantic Bight sediments, $57 \%$ of total mineralized nitrogen was lost as $\mathrm{N}_{2}$, while $37 \%$ entered the water column as $\mathrm{NH}_{4}{ }^{+}$and $6 \%$ as $\mathrm{NO}_{3}{ }^{-}+\mathrm{NO}_{2}{ }^{-}$ (Laursen \& Seitzinger 2002). In Massachusetts Bay sediments, $60 \%$ of total mineralized nitrogen was lost as $\mathrm{N}_{2}$, while $34 \%$ was released to the water column as $\mathrm{NH}_{4}{ }^{+}$and $6 \%$ as $\mathrm{NO}_{3}{ }^{-}+\mathrm{NO}_{2}^{-}$; whereas in Stellwagen Basin, $72 \%$ of total mineralized nitrogen was lost as $\mathrm{N}_{2}$, whereas $16 \%$ was released as $\mathrm{NH}_{4}{ }^{+}$and $11 \%$ as $\mathrm{NO}_{3}{ }^{-}$ $+\mathrm{NO}_{2}$ (Hopkinson et al. 2001).

\section{CONCLUSIONS}

Benthic fluxes of nutrients resulting from organic matter remineralization in sediments of the near-shore northeastern shelf of the Gulf of Cádiz provide, respectively, about 15 and $12 \%$ of inorganic nitrogen and phosphorus required for phytoplankton primary production. Furthermore, these sediments mineralize approximately $47 \%$ of the primary production carbon. These results highlight the significance of benthic remineralization processes in the biogeochemistry of coastal environments. In relation to sediment $\mathrm{N}$ cycling, estimated denitrification rates accounted for between 9 and $13 \%$ of total organic matter remineralization and were found to be correlated with the organic carbon content of surface sediments. Between 61 and $67 \%$ of mineralized $\mathrm{N}$ was estimated to be lost as $\mathrm{N}_{2}$ via denitrification, with the remaining portion recycled mostly as $\mathrm{NH}_{4}{ }^{+}$. The regeneration of $\mathrm{NH}_{4}{ }^{+}$was closely linked to carbon oxidation rates, which were strongly influenced by bulk organic carbon in surface sediments. Sediments behaved as a net source of dissolved $\mathrm{N}_{2} \mathrm{O}$ and, although benthic $\mathrm{N}_{2} \mathrm{O}$ fluxes were not significant in terms of the sedimentary $\mathrm{N}$ cycle, they were a considerable potential source of this gas to the water column. Phosphorus regeneration seemed to be mainly controlled by bottom water oxygen concentrations. The low P:C flux ratios reported indicated that up to $75 \%$ of mineralized P could be retained in the sediments by adsorption or mineral precipitation. No clear trends were observed between the macrofaunal community and benthic carbon mineralization rates or nutrient recycling.

Acknowledgements. We thank the crew of the RV 'Mytilus' for their valuable assistance during the cruises and S. Smith for language correction. This work was supported by the Spanish Commission for Research and Development (CICYT) under contract CTM2005-01364/MAR. S.F. was funded by a grant from the Spanish MECD. The manuscript benefited from the comments provided by 4 anonymous reviewers.

\section{LITERATURE CITED}

Aller RC (1982) The effect of macrobenthos on chemical properties of marine sediment and overlying water. In: Tevesz MJS (ed) Animal-sediment relations. The biogenic alteration of sediments. Plenum Press, New York, p 53-104

Aller RC, Aller JY (1998) The effect of biogenic irrigation intensity and solute exchange on diagenetic reaction rates in marine sediments. J Mar Res 56:905-936

Aller RC, Yingst JY (1978) Biogeochemistry of tubedwellings: a study of the sedentary polycheate Amperite ornata. J Mar Res 36:201-254

> Arnosti C, Holmer M (2003) Carbon cycling in a continental margin sediment: contrasts between organic matter characteristics and remineralization rates and pathways. Estuar Coast Shelf Sci 58:197-208

> Bange HW (2006) Nitrous oxide and methane in European coastal waters. Estuar Coast Shelf Sci 70:361-374

Berelson WM, Reggie D, Longmore A, Kilgore T, Nicholson G, Skyring G (1998) Benthic nutrient recycling in Port Phillip Bay, Australia. Estuar Coast Shelf Sci 46:917-934

Berelson WM, McManus J, Coale KH, Johnson KS and others (2003) A time series of benthic flux measurements from Monterey Bay, CA. Cont Shelf Res 23:457-481

Blott SJ, Pye K (2001) GRADISTAT: a grain size distribution and statistics package for the analysis of unconsolidated sediments. Earth Surf Process Landf 26:1237-1248

Bronk DA, Steinberg DK (2008) Nitrogen regeneration. In: Capone D, Bronk D, Mulholland M, Carpenter E (eds) Nitrogen in the marine environment, 2nd edn. Academic Press, San Diego, CA, p 385-467

> Christensen JP (1994) Carbon export from continental shelves, denitrification and atmospheric carbon dioxide. Cont Shelf Res 14:547-576

Christensen PB, Rysgaard S, Sloth NP, Dalsgaard T, Schwærter S (2000) Sediment mineralization, nutrient fluxes, denitrification and dissimilatory nitrate reduction to ammonium in an estuarine fjord with sea cage trout farms. Aquat Microb Ecol 21:73-84

Cowan JLW, Boynton WR (1996) Sediment-water oxygen and nutrient exchanges along the longitudinal axis of Chesapeake Bay: seasonal patterns, controlling factors and ecological significance. Estuaries 19:562-580

> Crutzen PJ, Schmailzl U (1983) Chemical budgets of the stratosphere. Planet Space Sci 31:1009-1032

> Dalsgaard T, Thamdrup B, Canfield DE (2005) Anaerobic ammonium oxidation (anammox) in the marine environment. Res Microbiol 156:457-464

> de la Paz M, Gómez-Parra A, Forja JM (2007) Inorganic carbon dynamic and air-water $\mathrm{CO}_{2}$ exchange in the Guadalquivir Estuary (SW Iberian Peninsula). J Mar Syst 68:265-277 
Devol AH (2008) Denitrification including anammox. In: Capone D, Bronk D, Mulholland M, Carpenter E (eds) Nitrogen in the marine environment, 2nd edn. Academic Press, San Diego, CA, p 263-301

El Rayis OA (1985) Re-assessment of the titration methods for determination of organic carbon in recent sediments. Rapp Comm Int Mer Mediterr 29:45-47

Enriquez S, Duarte CM, Sand-Jensen K (1993) Patterns in decomposition rates among photosynthetic organisms: the importance of detritus C:N:P content. Oecologia 94: $457-471$

Fasham MJR, Ducklow HW, McKelvie SM (1990) A nitrogenbased model of plankton dynamics in the oceanic mixed layer. J Mar Res 48:591-639

Fauchald K, Jumars PA (1979) The diet of worms: a study of polychaete feeding guilds. Oceanogr Mar Biol 17:193-284

Ferrón S, Alonso-Pérez F, Castro CG, Ortega T and others (2008) Hydrodynamic characterization and performance of an autonomous benthic chamber for use in coastal systems. Limnol Oceanogr Methods 6:558-571

Ferrón S, Ortega T, Forja JM (2009) Benthic fluxes in a tidal salt marsh creek affected by fish farm activities: Río San Pedro (Bay of Cádiz, Spain). Mar Chem 113:50-62

Forja JM, Blasco J, Gómez-Parra A (1994) Spatial and seasonal variation of in situ benthic fluxes in the Bay of Cadiz (South-West Spain). Estuar Coast Shelf Sci 39:127-141

Forja JM, Gómez-Parra A (1998) Measuring nutrient fluxes across the sediment-water interface using benthic chambers. Mar Ecol Prog Ser 164:95-105

Forja JM, Ortega T, DelValls TA, Gómez-Parra A (2004) Benthic fluxes of inorganic carbon in shallow coastal ecosystems of the Iberian Peninsula. Mar Chem 85:141-156

Froelich PN, Klinkhammer G, Bender ML, Luedtki NA and others (1979) Early oxidation of organic matter in pelagic sediments of the eastern equatorial Atlantic: suboxic diagenesis. Geochim Cosmochim Acta 43:1075-1095

Gaudette HE, Flight WR, Torner L, Folger DW (1974) An inexpensive titration method for the determination of organic carbon in recent sediments. J Sediment Petrol 44:249-253

Gibbs M, Funnel G, Pickmere S, Norkko A, Hewitt J (2005) Benthic nutrient fluxes along an estuarine gradient: influence of the pinnid bivalve Atrina zelandica in summer. Mar Ecol Prog Ser 288:151-164

Gómez-Parra A, Forja JM (1992) Significance of benthic regeneration in nutrient balance in the Bay of Cadiz, south-west Spain (a shallow semi-closed coastal ecosystem). Sci Total Environ 126:1079-1086

Hansen HP, Grasshoff K (1983) Automated chemical analysis. In: Grasshoff K, Ehrhardt M, Kremling K (eds) Methods of seawater analysis. Verlag Chemie, Weinheim, p 347-395

Herbert RA (1999) Nitrogen cycling in coastal marine ecosystems. FEMS Microbiol Rev 23:563-590

> Hopkinson CS Jr, Fallon RD, Jansson BO, Schulauer JP (1991) Community metabolism and nutrient cycling at Gray's Reef, a hard bottom habitat in the Georgia Bight. Mar Ecol Prog Ser 73:105-120

- Hopkinson CS Jr, Giblin AE, Tucker J (2001) Benthic metabolism and nutrient regeneration on the continental shelf of Eastern Massachusetts, USA. Mar Ecol Prog Ser 224:1-19

- Huertas E, Navarro G, Rodríguez-Gálvez S, Prieto L (2005) The influence of phytoplankton biomass on the spatial distribution of carbon dioxide in surface sea water of a coastal area of the Gulf of Cádiz (southwestern Spain). Can J Bot 83:929-940

Ingall E, Jahnke R (1997) Influence of water-column anoxia on the elemental fractionation of phosphorus during sediment diagenesis. Mar Geol 139:219-229
Jahnke RA (2005) Transport processes and organic matter cycling in coastal sediments. In: Robinson AR, Brink KH (eds) The global coastal ocean. Multi-scale interdisciplinary processes. Harvard University Press, Cambridge, MA, p 163-191

Jahnke RA, Jahnke DB (2000) Rates of C, N, P and Si recycling and denitrification at the US Mid-Atlantic continental slope depocenter. Deep Sea Res I 47:1405-1428

Jahnke RA, Nelson JR, Marinelli RL, Eckman JE (2000) Benthic flux of biogenic elements on the Southeastern US continental shelf: influence of pore water advective transport and benthic microalgae. Cont Shelf Res 20:109-127

Joye SB, Anderson IC (2008). Nitrogen cycling in coastal sediments. In: Capone D, Bronk D, Mulholland M, Carpenter E (eds) Nitrogen in the marine environment, 2nd edn. Academic Press, San Diego, CA, p 867-915

Koroleff F (1983) Determination of silicon. In: Grasshoff K, Ehrhardt M, Kernling K (eds) Methods of sea water analysis. Verlag Chemie, Weinheim, p 174-183

Khalil MAK, Rasmussen RA (1992) The global sources of nitrous oxide. J Geophys Res 97:14651-14660

> Lansard B, Rabouille C, Denis L, Grenz C (2008) In situ oxygen uptake rates by coastal sediments under the influence of the Rhône River (NW Mediterranean Sea). Cont Shelf Res 28:1501-1510

Laursen AE, Seitzinger SP (2002) The role of denitrification in nitrogen removal and carbon mineralization in MidAtlantic Bight sediments. Cont Shelf Res 22:1397-1416

> Lehmann MF, Sigman DM, Berelson WB (2004) Coupling the ${ }^{15} \mathrm{~N} /{ }^{14} \mathrm{~N}$ and ${ }^{18} \mathrm{O} /{ }^{16} \mathrm{O}$ of nitrate as a constraint on benthic nitrogen cycling. Mar Chem 88:1-20

> Lobo FJ, Sánchez R, González R, Dias JMA, HernándezMolina FJ, Fernández-Salas LM, Díaz del Río V, Mendes I (2004) Contrasting styles of the Holocene highstand sedimentation and sediment dispersal systems in the northern shelf of the Gulf of Cádiz. Cont Shelf Res 24:461-482

- McManus J, Berelson WM, Coale KH, Johnson KS, Kilgore TE (1997) Phosphorus regeneration in continental margin sediments. Geochim Cosmochim Acta 61:2891-2907

Mortimer RJG, Davey JT, Krom MD, Watson PG, Frickers PE, Clifton RJ (1999) The effect of macrofauna on porewater profiles and nutrient fluxes in the intertidal zone of the Humber Estuary. Estuar Coast Shelf Sci 48:683-699

Mouriño C, Fraga F (1985) Determinación de nitratos en agua de mar. Invest Pesq (Spain) 49:81-96

- Navarro G, Ruiz J (2006) Spatial and temporal variability of phytoplankton in the Gulf of Cádiz through remote sensing images. Deep Sea Res II 53:1241-1260

Navarro G, Ruiz J, Huertas IE, García CM, Criado-Aldenueva F, Echevarría F (2006) Basin-scale structures governing the position of the deep fluorescence maximum in the Gulf of Cádiz. Deep Sea Res II 53:1261-1281

Nixon SW (1981) Remineralization and nutrient cycling in coastal marine ecosystems. In: Neilson BJ, Cronin LE (eds) Estuaries and nutrients. Humana, New York, p 111-138

Parada JM (2005) Cartografía biosedimentaria y comunidades bentónicas de los fondos blandos submareales de las Rías de Pontevedra y Aldán y la Ensenada de A Lanzada. PhD dissertation, Universidad de Santiago de Compostela

Patrick WH Jr, Khalid RA (1974) Phosphate release and sorption by soils and sediments: effect of aerobic and anaerobic conditions. Science 186:53-55

Pearson TH (1971) The benthic ecology of Loch Linnhe and Loch Eil, a sea-loch system on the west coast of Scotland. III. The effect on the benthic fauna of the introduction of 
pulp mill effluent. J Exp Mar Biol Ecol 6:211-233

Ricciardi A, Bourget E (1998) Weight-to-weight conversion factors for marine benthic macroinvertebrates. Mar Ecol Prog Ser 163:245-251

Robinson AD, Nedwell DB, Harrison RM, Ogilvie BD (1998) Hypernutrified estuaries as sources of $\mathrm{N}_{2} \mathrm{O}$ emission to the atmosphere: the estuary of the River Colne, Essex, UK. Mar Ecol Prog Ser 164:59-71

Rodhe H (1990) A comparison of the contribution of various gases to the greenhouse effect. Science 248:1217-1219

Rysgaard S, Risgaard-Petersen N, Sloth NP (1996) Nitrification, denitirification and nitrate ammonification in sediments of two coastal lagoons in southern France. Hydrobiologia 329:133-141

Seitzinger SP (1988) Denitrification in freshwater and coastal marine ecosystems: ecological and geochemical significance. Limnol Oceanogr 33:702-724

Seitzinger SP, Giblin AE (1996) Estimating denitrification in North Atlantic continental shelf sediments. Biogeochemistry 35:235-260

Seitzinger SP, Kroeze C, Styles RV (2000) Global distribution of $\mathrm{N}_{2} \mathrm{O}$ emissions from aquatic systems: natural emissions and anthropogenic effects. Chemosphere - Glob Chang Sci 2:267-279

Ståhl H, Tengberg A, Brunnegård J, Bjørnbom E and others (2004a) Factors influencing organic carbon recycling and burial in Skagerrak sediments. J Mar Res 62:867-907

Ståhl H, Hall POJ, Tengberg A, Josefson A, Streftaris N, Zenetos A, Karageorgis AP (2004b) Respiration and sequestering of organic carbon in shelf sediments of the oligotrophic northern Aegean Sea. Mar Ecol Prog Ser 269: 33-48

Thamdrup B, Dalsgaard T (2002) Production of $\mathrm{N}_{2}$ through anaerobic ammonium oxidation coupled to nitrate reduction in marine sediments. Appl Environ Microbiol 68: $1312-1318$

Tovar A, Moreno C, Manuel-Vez MP, García-Vargas M (2000) Environmental implications of intensive marine aquaculture in earthen ponds. Mar Pollut Bull 40:981-988

Van Geen A, Adkins JF, Boyle EA, Nelson CH, Palanques A (1997) A $120 \mathrm{yr}$ record of widespread contamination from mining of the Iberian pyrite belt. Geology 25:291-294

Weiss RF, Price BA (1980) Nitrous oxide solubility in water and seawater. Mar Chem 8:347-359

Wenzhöfer F, Glud RN (2004) Small-scale spatial and temporal variability in coastal benthic $\mathrm{O}_{2}$ dynamics: effects of fauna activity. Limnol Oceanogr 49:1471-1481

Wollast R (2002) Continental margins - review of geochemical settings. In: Wefer G, Billet D, Hebbeln D, Jørgensen $\mathrm{BB}$, Schlüter $\mathrm{M}$, van Weering TCE (eds) Ocean margin systems. Springer-Verlag, Berlin, p 15-31

Appendix 1. Abundance (ind. $\mathrm{m}^{-2}$ ) and species richness of benthic macrofaunal species collected at the 9 sites (see Fig. 1) in November 2006. The trophic group (TG) is also included (C: carnivores; S: suspension feeders; SD: surface deposit feeders; SSD: sub-surface deposit feeders; O: others)

\begin{tabular}{|c|c|c|c|c|c|c|c|c|c|c|}
\hline & TG & GL1 & GL2 & GL3 & GL4 & $\mathrm{BC} 1$ & $\mathrm{BC} 2$ & $\mathrm{BC} 3$ & $\mathrm{BC} 4$ & $\mathrm{BC} 5$ \\
\hline \multicolumn{11}{|l|}{ Polychaetes } \\
\hline Ampharetidae & $\mathrm{SD}$ & & 10 & & & & & & 30 & \\
\hline Capitella capitata & SSD & & & & 10 & 20 & & & & \\
\hline Chaetozone sp. & SD & & & & & & 10 & & 20 & \\
\hline Diopatra neapolitana & $\mathrm{C}$ & 10 & & & & 40 & & & & \\
\hline Diplocirrus sp. & SD & & & & 10 & & & & & \\
\hline Euclymene sp. & SSD & 20 & & & & 130 & 310 & 10 & & 10 \\
\hline Galathowenia sp. & $\mathrm{S}$ & & 10 & 10 & & & 20 & & 10 & \\
\hline Glycera sp. & $\mathrm{C}$ & & 20 & & 20 & & 40 & & 10 & 50 \\
\hline Glycera unicornis & $\mathrm{C}$ & & 10 & 10 & & & & & & 40 \\
\hline Glycinde sp. & $\mathrm{C}$ & & & & & & 50 & & & 10 \\
\hline Hesionidae & $\mathrm{C}$ & & 40 & 40 & 10 & 50 & 60 & & 10 & 20 \\
\hline Heteromastus filiformis & SSD & 50 & 10 & 60 & 50 & & & & 70 & 30 \\
\hline Hyalinoecia sp. & $\mathrm{C}$ & & & & & & & & 20 & \\
\hline Laonice cirrata & SD & & 20 & 240 & 200 & & 30 & & 50 & 30 \\
\hline Lumbrineris sp. & $\mathrm{C}$ & 130 & 300 & 430 & 390 & & 40 & & 260 & 420 \\
\hline Magelona alleni & SD & & & & 10 & & 10 & & 10 & \\
\hline Magelona minuta & $\mathrm{SD}$ & 10 & 140 & 230 & 100 & & 350 & & 280 & 150 \\
\hline Maldane glebifex & SSD & & 40 & 10 & & & & & 30 & 100 \\
\hline Mediomastus fragilis & SSD & & & & & 20 & 40 & 40 & 10 & \\
\hline Melinna palmata & SD & 40 & & & & & & & & \\
\hline Monticellina sp. & SD & & 10 & & 40 & 160 & 40 & & 90 & 10 \\
\hline Nephtys sp. & $\mathrm{C}$ & 50 & 30 & 60 & 10 & 260 & 30 & 80 & 70 & 10 \\
\hline Notomastus sp.1 & SSD & & 10 & 20 & 20 & & & & 80 & 80 \\
\hline Notomastus sp. 2 & SSD & & & & & 20 & 10 & & & \\
\hline
\end{tabular}


Appendix 1 (continued)

\begin{tabular}{|c|c|c|c|c|c|c|c|c|c|c|}
\hline & TG & GL1 & GL2 & GL3 & GL4 & $\mathrm{BC} 1$ & $\mathrm{BC} 2$ & $\mathrm{BC} 3$ & $\mathrm{BC} 4$ & BC5 \\
\hline Orbiniidae & SSD & & & & & & & 10 & & 10 \\
\hline Owenia fusiformis & $\mathrm{S}$ & & & & & & 10 & & & \\
\hline Paraonidae & SSD & & 90 & 280 & 150 & 10 & 30 & & 150 & 70 \\
\hline Pectinaria sp. & SSD & & 10 & & & & & & & \\
\hline Phyllodoce sp. & $\mathrm{C}$ & & & & & 10 & 10 & & & \\
\hline Phyllodocidae & $\mathrm{C}$ & & & & 20 & & & & 40 & 10 \\
\hline Polycirrus sp. & $\mathrm{SD}$ & 50 & 10 & & & & & & & \\
\hline Polydora sp. & $\mathrm{SD}$ & 10 & & & & 10 & & & & 20 \\
\hline Prionospio sp.1 & $\mathrm{SD}$ & 10 & 50 & 50 & 40 & 260 & 70 & & 10 & 10 \\
\hline Prionospio sp.2 & $\mathrm{SD}$ & & & & & 90 & & 160 & & \\
\hline Sabellidae & $\mathrm{S}$ & & & 10 & & & 10 & 10 & 10 & \\
\hline Scolelepis sp. & $\mathrm{SD}$ & & & & & & 20 & & & \\
\hline Sigalion mathildae & $\mathrm{C}$ & & & & & & & 10 & & \\
\hline Sphaerosyllis sp. & $\mathrm{C}$ & & & & & 30 & & & & \\
\hline Spiochaetopterus sp. & $\mathrm{SD}$ & & 50 & 30 & 10 & & 40 & & & \\
\hline Spiophanes sp. & $\mathrm{SD}$ & & & & & 10 & 280 & & & \\
\hline Sternaspis scutata & SSD & 220 & 10 & 30 & 110 & & & & 10 & \\
\hline Terebellidae & SD & & & & & & 10 & & & \\
\hline Terebellides stroemi & $\mathrm{SD}$ & & & 10 & & & 10 & & 10 & 10 \\
\hline \multicolumn{11}{|l|}{ Molluscs } \\
\hline Abra sp. & $\mathrm{SD}$ & & 10 & & 10 & & & & 10 & 10 \\
\hline Acteon tornatilis & $\mathrm{C}$ & 10 & & & & & & & & \\
\hline Antalis novemcostata & $\mathrm{SD}$ & & 40 & & & & 40 & 10 & 50 & 60 \\
\hline Bivalvia & - & & 20 & 10 & & 10 & 90 & 20 & 50 & 20 \\
\hline Chamelea striatula & $\mathrm{S}$ & & 10 & & 10 & & & & 10 & 10 \\
\hline Corbula gibba & $\mathrm{SD}$ & 20 & 30 & 30 & 40 & 50 & 50 & & 20 & 30 \\
\hline Cylichna cylindracea & $\mathrm{C}$ & & 10 & & & & 10 & & & \\
\hline Epitonium sp. & $\mathrm{O}$ & & 10 & & & & 30 & & & \\
\hline Gastropoda & $\mathrm{O}$ & & & & & & & & & 50 \\
\hline Hyala vitrea & $\mathrm{O}$ & & 160 & 80 & 20 & & 90 & & 70 & 80 \\
\hline Kurtiella bidentata & $\mathrm{S}$ & & 10 & 10 & & & & & & 30 \\
\hline Mangelia sp. & $\mathrm{C}$ & & 10 & & & & 40 & & & \\
\hline Nassarius sp. & $\mathrm{O}$ & & & & & 10 & & & & \\
\hline Nucula sp. & $\mathrm{SD}$ & & 50 & 110 & & & 70 & 10 & 130 & 30 \\
\hline Nuculana sp. & $\mathrm{SD}$ & & & & & & & 30 & & \\
\hline Spisulla sp. & $\mathrm{S}$ & & & & & & & 10 & & \\
\hline Tellina serrata & $\mathrm{SD}$ & & & & & & & & 10 & \\
\hline Tellinidae & $\mathrm{SD}$ & & 10 & 10 & & & 30 & 20 & 10 & 40 \\
\hline Thyasira flexuosa & $\mathrm{SD}$ & & 160 & 150 & & & 40 & & 140 & 40 \\
\hline Turritella communis & $\mathrm{O}$ & & 130 & 80 & 10 & & & 50 & 70 & 560 \\
\hline \multicolumn{11}{|l|}{ Crustaceans } \\
\hline Ampelisca brevicornis & $\mathrm{SD}$ & & & & & 10 & & & & \\
\hline Ampelisca sp. & $\mathrm{SD}$ & & & 30 & & & 50 & & 20 & 40 \\
\hline Amphipoda & $\mathrm{SD}$ & & 10 & & & 40 & & 30 & & 20 \\
\hline Apseudes sp. & $\mathrm{SD}$ & & & & 10 & 20 & & 50 & & 10 \\
\hline Bodotria sp. & $\mathrm{SD}$ & & & 10 & & 10 & 10 & & & 20 \\
\hline Cumacea & $\mathrm{SD}$ & & & 10 & & 10 & & 10 & & 20 \\
\hline Diastylis sp. & $\mathrm{SD}$ & & 10 & 30 & 10 & & 40 & 10 & 10 & 20 \\
\hline Diogenes pugilator & $\mathrm{SD}$ & & & & & 10 & & 40 & & 130 \\
\hline Eurydice sp. & $\mathrm{O}$ & & & & & & & 10 & & \\
\hline Gnathiidae & $\mathrm{C}$ & & & & & & & & 10 & \\
\hline Harpinia pectinata & SSD & & & 60 & 10 & & & & 10 & \\
\hline Iphinoe sp. & $\mathrm{SD}$ & & 10 & 10 & & & & 10 & 10 & 10 \\
\hline Leptocheirus sp. & $\mathrm{SD}$ & & & & & & & & 10 & \\
\hline Leucothoe incisa & $\mathrm{SD}$ & & & & & & 10 & & 10 & 20 \\
\hline Liocarcinus sp. & $\mathrm{C}$ & & & & & & & & & 30 \\
\hline Nebalia sp. & $\mathrm{SD}$ & & & & & & 10 & & & \\
\hline Paguroidea & $\mathrm{SD}$ & & & & & & & 20 & 10 & 70 \\
\hline Processa sp. & $\mathrm{C}$ & & & & & & & & & 10 \\
\hline
\end{tabular}


Appendix 1 (continued)

\begin{tabular}{|c|c|c|c|c|c|c|c|c|c|c|}
\hline & $\mathrm{TG}$ & GL1 & GL2 & GL3 & GL4 & $\mathrm{BC} 1$ & $\mathrm{BC} 2$ & $\mathrm{BC} 3$ & $\mathrm{BC} 4$ & BC5 \\
\hline Tanaidacea & $\mathrm{SD}$ & & & & & & & 10 & & \\
\hline Upogebia sp. & $\mathrm{O}$ & & & & & & 10 & & & 10 \\
\hline Urothoe sp. & $\mathrm{S}$ & & & & & 130 & & & & \\
\hline \multicolumn{11}{|l|}{ Echinoderms } \\
\hline Amphiura filiformis & $\mathrm{S}$ & & & & & & & & 10 & 10 \\
\hline Amphiura sp. & $\mathrm{S}$ & & 40 & & & & & & & 20 \\
\hline Echinocardium cordatum & SSD & & & & & 10 & 140 & & & \\
\hline Holothuroidea & - & & 20 & 10 & & & & & & \\
\hline Ophiuroidea & $\mathrm{S}$ & & & & 10 & 10 & & & & \\
\hline \multicolumn{11}{|l|}{ Other invertebrates } \\
\hline Cerebratulus sp. & $\mathrm{C}$ & & & 10 & & & & & & \\
\hline Chaetognatha & $\mathrm{C}$ & & & & & 10 & & & & \\
\hline Edwardsia sp. & $\mathrm{C}$ & & & & 10 & & & & & \\
\hline Nemertina & $\mathrm{C}$ & & 100 & 140 & 130 & 20 & 130 & 10 & 230 & 30 \\
\hline Oligochaeta & $\mathrm{O}$ & & & & & 20 & & & 10 & 30 \\
\hline Phascolion strombi & $\mathrm{SD}$ & & & & & & 10 & & & \\
\hline Phoronida & $\mathrm{S}$ & 30 & 20 & 10 & 20 & & 50 & & & 10 \\
\hline Pycnogonida & $\mathrm{C}$ & & & & & & 20 & & & \\
\hline Abundance (ind. $\mathrm{m}^{-2}$ ) & & 660 & 1740 & 2320 & 1490 & 1490 & 2500 & 670 & 2190 & 2560 \\
\hline Species richness & & 14 & 40 & 34 & 29 & 30 & 45 & 24 & 44 & 49 \\
\hline
\end{tabular}

Editorial responsibility: Hans Heinrich Janssen, Oldendorf/Luhe, Germany
Submitted: August 26, 2008; Accepted: July 6, 2009 Proofs received from author(s): September 1, 2009 